\title{
Näyttöperusteisuus ja yritysten verotus: ekonomismin nousu suomalaisen yhteisöveropolitiikan tiedontuotannossa
}

Matti Ylönen, tutkijatohtori, valtiotieteellinen tiedekunta, Helsingin yliopisto

Jussi Jaakkola, tohtorikoulutettava, oikeustieteellinen tiedekunta, Turun yliopisto

Leevi Saari, valtiotieteiden kandidaatti, valtiotieteellinen tiedekunta, Helsingin yliopisto

Heikki Hiilamo, professori, valtiotieteellinen tiedekunta, Helsingin yliopisto

\begin{abstract}
Abstrakti
Suomalaista poliittista päätöksentekoa on 2000-luvulla pyritty sitomaan vahvemmin tutkittuun tietoon. Näyttöperusteinen päätöksenteko on ollut tähän liittyen keskeinen käsite. Sille annetut määritelmät rajaavat päätöksenteon kannalta relevanttina pidetyn tutkimuksen kokonaisuutta. Tämän tutkimuksen tieteenalapohjan ja metodologioiden kokonaisuuteen on kiinnitetty yllättävän vähän huomiota, vaikka se ohjaa monin tavoin politiikkaa. Tutkimme tiedon ja päätöksenteon suhdetta tarkastelemalla suomalaisen yritysveropolitiikan taustalla vaikuttaneen tiedon muutoksia 1990-luvun alusta vuoteen 2014. Esitämme tässä keskustelunavauksessa, että näyttöperusteinen päätöksenteko on korostanut yhteisöveropolitiikassa uusklassisesta taloustieteestä johdettujen syy-seuraussuhteiden merkitystä. Etenkin vuoden 2014 yhteisöverouudistuksessa talousteoreettiset käyttäytymisoletukset nousivat merkittävään rooliin uudistuksen perusteluissa. Näitä taustaoletuksia ei avattu kunnolla julkisessa keskustelussa, mikä on vaikeuttanut niiden soveltuvuuden ja rajoitteiden arvioimista. Peräänkuulutamme huomiota näyttöperusteisen politiikan pohjana käytettyihin tutkimuksiin ja niiden taustaoletuksiin. Kehotamme myös avaamaan niitä paremmin laajalle yleisölle kriittisen keskustelun ja demokraattisen läpinäkyvyyden tukemiseksi. Politiikkaa ohjaavaa tutkimusta tulisi perustaa taloustieteellisen analyysin lisäksi juridiseen tuntemukseen erilaisista sääntely-ympäristöistä. Myös yritysten toimintaan vaikuttavien tekijöiden syvällisempi käytännön tarkastelu olisi hyödyllistä.
\end{abstract}




\section{Johdanto}

Yritykset vahvistaa näyttöperusteista päätöksentekoa ovat muovanneet suomalaista politiikkaa merkittävästi 2000-luvulla. Näyttöperusteisuuden pyrkimyksenä on tuottaa eri tietolähteisiin perustuen "mahdollisimman todistusvoimaista ja vakuuttavaa näyttöä siitä, mikä toimii" (Lähteenmäki-Smith ja Kuitunen 2015, 125). Näyttöperusteisen päätöksenteon juuret ovat terveyden ja lääketieteen tutkimuksessa, jossa hyödynnetään tyypillisesti kokeellisia asetelmia sekä laajojen tutkimusaineistojen pohjalta tehtyjä syy-yhteyksiä selvittäviä tilastollisia tutkimuksia (Lähteenmäki-Smith ja Kuitunen 2015). Vakuuttava näyttö samaistetaan usein empiirisesti todennettavaan kvantitatiiviseen havainnointiin. Keskittyminen pelkästään näyttöön on kuitenkin harhaanjohtavaa. Näytön valikoituminen ja sen tulkinta edellyttää laajempia teoreettisia ennakko-oletuksia, jotka yhdessä muodostavat politiikassa käytettävän tietopohjan. Kysymykset politiikan kannalta relevanttien tietolähteiden valikoitumisesta sekä tieteellisten paradigmojen ja niiden pohjalta tehtyjen politiikkatoimien suhteesta ovat jääneet liian vähälle huomiolle.

Lähestymme tiedon ja politiikan väliseen suhteeseen liittyviä kysymyksiä yhteisöverotukseen keskittyvällä tutkimuksella. Yhteisöverotus on kiinnostava linssi akateemisen tutkimuksen ja näyttöperusteisen päätöksenteon suhteen hahmottamiseen. Vuonna 2018 yhteisöveron tuotto oli noin 5,9 miljardia euroa, joten yhteisöverotuksen muutoksia pohjustavalla tiedolla on konkreettisia yhteiskunnallisia vaikutuksia. Lisäksi aiheen tutkiminen vaatii sekä taloudellisten että oikeudellisten kysymysten huomiointia, mikä hankaloittaa aiheen käsittelyä niin politiikassa, mediassa kuin kapeasti yhdelle tieteenalalle keskittyvässä akateemisessa tutkimuksessakin. Tämä haaste on korostunut etenkin 2010-luvulla, kun talousteoreettiset taustaoletukset ovat saaneet vahvemman roolin veropolitiikan tiedontuotannossa.

Veropolitiikasta on viime aikoina keskusteltu tutkimuksessa ja julkisuudessa siihen liittyvien poliittisten kiistojen, lobbauksen ja oikeustieteilijöiden eturistiriitojen näkökulmasta (Konttinen 2019; Valtanen 2019; Raitasuo 2018, 2019). Tässä artikkelissa nämä tekijät ovat sivuroolissa. Haastattelemamme tutkijat, asiantuntijat ja viranhaltijat ovat lähtökohtaisesti vähäisemmän lobbauksen kohteena kuin kansanedustajat, ministerit ja heidän avustajansa. Tutkijoiden, asiantuntijoiden ja viranhaltijoiden näkökulmat ovat kuitenkin 
ensisijaisen tärkeitä erityisesti tiedon ja politiikan välisen suhteen ja siihen liittyvän vallankäytön tarkastelussa.

Tarkastelemme yhteisöverouudistuksia ohjanneen tiedontuotannon muutoksia 1990-luvun alusta 2010-luvun puoliväliin saakka. Tutkimukseemme valikoituivat erityisesti vuoden 1993, 2005 ja 2014 verouudistukset. 1990-luvun alussa erityisen keskeinen oli vuoden 1993 suuri verouudistus, jolle pääministeri Harri Holkerin (kok.) hallituksen uudistukset olivat luoneet jo pohjaa 1980-luvulta alkaen. Uudistuksen taustalla vaikutti keskeisesti myös valtiovarainministeriön asettama asiantuntijatyöryhmä ja ryhmän tuottama muistio (VM 1991). Vuonna 2002 julkaistiin Lasse Arvelan verotyöryhmän raportti (VM 2002) tuloverotuksen uudistamisesta sekä vähemmälle huomiolle jäänyt, valtioneuvoston kanslian yhteydessä toimivan talousneuvoston tekemä raportti (Talousneuvosto 2002). Arvelan työryhmän raportti ennen kaikkea pohjusti vuoden 2005 verouudistusta. Vuonna 2010 valmistui Martti Hetemäen verotyöryhmän raportti (VM 2010b, 2010c), jota puolestaan seurasivat Jyrki Kataisen (kok.) hallituksen verouudistukset, erityisesti vuoden 2014 merkittävä yhteisöverokannan lasku. Yritysverotusta ohjaavan tiedontuotannon muutoksia ei ole ennen tarkasteltu näin pitkällä aikavälillä.

Erityisenä tapaustutkimuksena käsittelemme vuoden 2014 yhteisöverouudistusta. Tuolloin tehdyn 4,5 prosenttiyksikön yhteisöverokannan alentamisen väitettiin johtavan merkittäviin positiivisiin käyttäytymisvaikutuksiin taloudessa. Näiden kerrottiin kasvattavan yritysveropohjaa ja maksavan uudistuksen takaisin 50-prosenttisesti (vuositasolla noin 480 miljoonaa euroa). Tällainen käyttäytymisvaikutusten huomioiminen oli ennenkuulumatonta yhteisöveropoliittisessa valmistelussa. Jäljitimme käyttäytymisvaikutusten tulon suomalaisen yhteisöveropolitiikan valmisteluun kansainvälisen verotaloustieteen katsausartikkeliin vuodelta 2008. Tämän artikkelin tarkastelu avaa kiinnostavia näkökulmia siihen, miten yhteiskuntatieteelliset ideat välittyvät politiikkaan.

Artikkeli pohjautuu laajaan haastattelu- ja tekstiaineistoon. Haastattelimme 21 yritysverotuksen keskeistä asiantuntijaa, taustavaikuttajaa ja alan kehitystä seurannutta toimijaa. Heistä pääosa oli tutkijoita tai viranhaltijoita, jotka ovat olleet näköalapaikoilla suomalaisen yhteisöveropolitiikan kehityksessä 1990tai 2000-luvulla. Aloitimme hastattelukierroksen haastattelemalla aihepiiriä pitkään seurannutta politiikan toimittajaa sekä muita taustavaikuttajia. 
Tutkimusaineiston kertyessä ja tutkimuskysymysten täsmentyessä laajensimme haastateltavajoukkoa siten, että saimme mahdollisimman kattavasti vastauksia artikkelin keskeisiin kysymyksiin.

Osa haastateltavista esiintyy artikkelissa nimellään. ${ }^{1}$ Osa halusi käyttää mahdollisuutta puhua anonyymisti. Näissä tapauksissa anonymiteetin avulla hankkeen käyttöön saatiin kattavin mahdollinen tieto silloinkin, kun haastateltavat eivät asemansa vuoksi pystyneet tai halunneet kertoa näkemyksiään julkisesti. Jotkut haastateltavat halusivat jakaa joitakin yksittäisiä huomioitaan anonyymisti. Haastateltavat on listattu liitteessä 1. Keskitymme ennen kaikkea lainvalmistelussa käytettyjen asiantuntijaryhmien työhön, niiden merkitykseen ja niiden tuottaman tiedon hyödyntämisen tapoihin. Saimme artikkelia varten käyttöömme myös taustamateriaalin, jota Valtiontalouden tarkastusvirasto oli kerännyt vuoden 2014 verouudistusta käsittelevään tarkastusraporttiinsa (VTV 2014). Viittaamme sen hastatteluihin anonyymisti, haastattelumuistiot tehneiden virkahenkilöiden kautta.

Artikkeli rakentuu johdannon lisäksi neljästä osiosta. Toisessa osiossa käymme läpi näyttöperusteisen tiedontuotannon nousua suomalaista hallintopolitiikkaa ohjaavaksi periaatteeksi ja kuvaamme niitä vääristymiä, joille näyttöperusteinen päätöksenteko on veropolitiikassa altis. Kolmannessa osiossa kuvaamme yhteisöverotusta muokanneita politiikkaprosesseja ja tutkitun tiedon asemaa näissä prosesseissa. Neljännessä osiossa käsittelemme näyttöperusteista päätöksentekoa koskevia löydöksiämme. Viimeisessä osiossa tarkastelemme tapaustutkimuksen löydöksiä suhteessa laajempaan muutokseen tiedon ja poliittisen päätöksenteon suhteessa.

Yhteenvetona toteamme, että näyttöperusteinen päätöksenteko on altista polkuriippuvuuksille. Polkuriippuvuudet seuraavat siitä, että päätöksenteossa tukeudutaan tietoon, jota ohjaavat tämän tiedon hankinnassa tyypillisesti hyödynnettävät tutkimusmetodit ja tutkimuksen taustalla olevien teorioiden taustaoletukset. Suomalaisessa yhteisöveropolitiikassa tämä on näkynyt erityisesti 2010-luvulla, kun lakimuutosten käyttäytymisvaikutukset otettiin mukaan poliittiseen valmisteluun. Johtopäätöstemme mukaan politiikan aito sitominen tutkittuun tietoon edellyttää herkkyyttä tiedon taustaoletuksille ja niiden vaikutuksille. Lisäksi yritysveropolitiikan tueksi tarvitaan monitieteellisyyttä, joka antaa tilaa tiedolle yritysten toimintaa ohjaavasta oikeudellisesta sääntelystä ja empiiriselle tutkimukselle esimerkiksi yritysten verosuunnittelukäytännöistä. 


\section{Näyttöperusteisen politiikan nousu suomalaisessa hallintokulttuurissa}

Suomalaista julkishallintoa ohjasi 1990-luvun alkuun asti "rationalistinen ja pragmatistinen legalismi" (af Ursin ja Vartola 2015, 89). Valtaosa keskushallinnon johtavista virkahenkilöistä oli juristeja, "hallinto oli tiukasti sidottu lakiin ja hallintoa koskevat keskeiset kysymykset koskivat laillisuutta, oikeusturvaa ja oikeusvarmuutta” (emt., 89-90). Oikeudellinen näkökulma edellyttää oikeusjärjestyksen rakenteellisten piirteiden tuntemusta ja oikeudellisille periaatteille perustuvaa päättelyä. Juridisessa tarkastelussa olennaista on tunnistaa oikeusjärjestyksestä juontuvat oikeudelliset rajat, jotka määräävät sekä hallinnollisen että poliittisen päätöksenteon liikkumatilaa. Päätösten tulee pysyä laillisuuden näkökulmasta tämän liikkumatilan puitteissa. Oikeudellisen tiedon kannalta keskeisessä roolissa ovat myös oikeusjärjestyksen systeemiset ja keskinäisriippuvaiset sääntelyratkaisut. Niiden tunteminen muodostaa perustan sille, että poliittisilla päätöksillä syntyvä sääntely on johdonmukaista lainsäädännön kokonaisuuden sekä sen tavoitteiden ja periaatteiden kanssa. Lisäksi oikeusjärjestelmien vertailulle perustuva tieto luo lähtökohdan poliittisten ja oikeudellisten ideoiden siirtymiselle kansallisten rajojen yli. Tämä palvelee oikeusjärjestelmän kehittämistä kansalliset rajat ylittävän poliittisen oppimisen merkityksessä. Varsinkin lainvalmistelun kannalta näitä voidaan pitää oikeustieteen keskeisimpinä tiedollisina funktioina.

Legalistinen hallintokulttuuri alkoi heiketä 1990-luvun vaihteessa, kun vallitsevaa hallintomallia alettiin muuttaa. Hallinnon kehittäminen mainittiin ensimmäisen kerran jo Holkerin hallituksen ohjelmassa vuonna 1987 (VM 2010a). Hallitusohjelma peräänkuulutti "ammattimaisuutta” päätöksentekoon. Tämän myötä managerialismi alkoi lyödä läpi osana suomalaista hallintokulttuuria (af Ursin ja Vartola 2015, 90; Heiskala ja Luhtakallio 2006; Kantola 2002; Koikkalainen 2012). Managerialismin myötä hallintoon tuotiin yksityiseltä sektorilta lainattuja, uuden julkisjohtamisen oppien mukaisia hallintokäytäntöjä, kuten erilaisia tulosmatriiseja ja suorituskykymittaristoja (Eräsaari 2011). Samalla laajapohjaisuutta ja konsensusta korostava hallintomalli alkoi väistyä. Ministerien itsenäisyys lisääntyi suhteessa hallitukseen. Tämä vahvisti selvityshenkilö- ja myöhemmin konsulttivetoista tiedontuotantoa politiikan eri alueilla (Kuusela ja Ylönen 2013; Ylönen ja Kuusela 2018). 
Managerialismin myötä suomalaisessa lainvalmistelussa korostui ajatus päätösten tehokkuudesta ja niiden vaikutusten seurannasta. Suomessa toteutettiin 1990-luvun puolivälin jälkeen useita lainvalmistelun kehittämishankkeita, joiden keskeinen tavoite oli kasvattaa vaikutusarvioiden roolia (Ilmakunnas, Junka ja Uusitalo 2008). Esimerkiksi Matti Vanhasen (kesk.) hallitus sitoutui vuoden 2007 strategia-asiakirjassaan tehostamaan lainsäädännön vaikutusten arviointia (VNK 2007). Sen mukaan lakien vaikutusten puutteellinen ennakointi ja toteutuneiden vaikutusten seuranta on yksi suomalaisen lainvalmistelun perusongelmista. Samana vuonna oikeusministeriö totesi, että "välittömien vaikutusten ohella [lainvalmistelussa] on tarkasteltava erilaisia välillisiä vaikutuksia eri kohderyhmien toimintaan ja käyttäytymiseen sekä pitkän aikavälin kerrannaisvaikutuksia” (OM 2007, 16).

Vaikutusarvioiden merkityksen vahvistuminen on kytkeytynyt osaltaan näyttöpohjaisen politiikan nousuun. Vaikutteita tähän on saatu muun muassa OECD:sta ja EU:sta. Taustalla on ollut yleinen pyrkimys "järkevöittää" julkishallintoa ja kytkeä sen toimintaa entistä tiukemmin tutkimustietoon. ${ }^{2}$ Vuoden 2010 maa-arviossaan OECD moitti Suomen hallintopolitiikkaa ohjaavia ikiaikaisia arvoja ja järjestelyjä, jotka sen mukaan estävät hallinnon uudistamista. Raportissa mainitaan esimerkkeinä Ruotsin ja Venäjän vallan ajalta periytyvä "formalismi ja legalismi”, joiden väitettiin yhä ohjaavan yhteiskunnallisen päätöksenteon eri osa-alueita (OECD 2010, 19). Tällaisten vaatimusten näkökulmasta suomalaisessa hallintokulttuurissa ja päätöksenteossa oli merkittävä tiedollinen aukko.

Erityisesti taloustieteilijät aktivoituivat 2010-luvun taitteessa keskustelemaan tavoista lisätä tutkimustiedon käyttöä päätöksenteossa tämän tiedollisen aukon täyttämiseksi. Vesa Vihriälän $(2008,14)$ mukaan taloustieteen taso oli selvästi kohentunut, ja tutkimuksen painopisteet olivat muuttuneet suuntaan, joka lisäsi tutkimuksen yhteiskunnallista relevanssia. Ari Hyytinen ja Otto Toivainen (2010, 429) totesivat, että lainvalmistelun tiedontuotannon katvealueita voidaan paikata lisäämällä tutkimusrahoitusta, mikä saattaisi edellyttää merkittävääkin resursoinnin kasvattamista. Tieteellisyys samaistettiin näissä kannanotoissa (kansan)taloustieteeseen ${ }^{3}$ ja relevantit tutkimusaineistot laajoihin empiirisiin tilastoaineistoihin, joita analysoimalla voitaisiin selvittää muuttujien syy-seuraussuhteita ja näin mahdollistaa vaikutusarvioiden perustaminen tutkittuun tietoon. Tälle vaihtoehtoisina 
tai täydentävinä lähestymistapoina voidaan kuitenkin nähdä esimerkiksi oikeudellis-institutionaalinen ymmärrys sääntely-ympäristöistä tai empiirinen, esimerkiksi tapaustutkimuksiin perustuva tieto yritysten toiminnasta ja sitä ohjaavista tekijöistä sekä syy-seuraussuhteista.

Eräs poliittisessa päätöksenteossa käytettävän tiedon kannalta merkittävä kysymys on tiedon kattavuus. Yksi tapa varmistaa tiedon kattavuus on Hyytisen ja Toivaisen (2010, 431) mukaan se, "että akateemisilla tutkijoilla teetetään laaja kirjallisuuskatsaus olemassa olevasta tutkimuksesta." Esimerkkinä he mainitsevat Britanniassa veropolitiikkaa luotsanneen taloustieteellisen Mirrlees Review'n (Mirrlees 2010), joka toimi innoittajana myös valtiosihteeri Martti Hetemäen johtaman verotyöryhmän raportille (VM 2010b, 2010c) Suomessa. Hyytisen ja Toivaisen $(2010,432)$ mielestä Mirrlees Review'n kaltaisiin laajoihin akateemisiin kirjallisuuskatsauksiin liittyvä julkisuus pienentää vaaraa siitä, että katsaus on jollain tavoin yksipuolinen tai tiedon tarvitsijan toiveita tai etukäteisnäkemyksiä myötäilevä, sillä tutkimuksen saama julkisuus ja avoimuus mahdollistavat sen ulkopuolisen tarkastelun.

Tiedon luotettavuuden kannalta on merkittävää, missä määrin poliittinen ohjaus vaikuttaa tiedontuotantoon ja sen lopputuloksiin. ${ }^{4}$ Tiedontuotantoa ohjaavat aina tietyt yhteiskunnalliset reunaehdot. Nämä puitteet määrittävät esimerkiksi rahoituksen kautta tutkimuksen suuntaa, ja näin ollen poliittista päätöksentekoa tukeva tiedonmuodostus kytkeytyy väistämättä myös poliittiseen ohjaukseen. Poliittisen päätöksenteon ja tutkitun tiedon suhde on toisin sanoen kaksisuuntainen: tutkimukseen perustuva näyttö luo perustaa politiikalle (evidence-based policy), mutta toisaalta poliittiset lähtökohdat ja viitekehykset määrittävät tiedon hankintaa tutkimuksessa (policy-based evidence) (Strassheim ja Kettunen 2014; Parkhurst 2017). Poliittisen päätöksenteon tiedolliset tarpeet muovaavat siis tutkitun tiedon ja politiikan välistä suhdetta (Rimkute ja Haverland 2015). ${ }^{5}$

Hallinnon kehittämislinjauksissa on korostettu viime aikoina muun muassa tiedontuotannon moninaisuutta ja laaja-alaisuutta sekä epävarmuuksien sietokykyä (esimerkiksi VNK 2011). On kuitenkin epäselvää, missä määrin nämä painotukset ovat näkyneet veropolitiikkaa ohjanneissa taloudellisissa vaikutusarvioissa. Tutkimuksemme perusteella vaikuttaa pikemminkin siltä, että suomalaista veropolitiikkaa on 2010-luvulle saavuttaessa ohjannut varsin yksioikoisesti uusklassisen talousteorian tiettyihin osa-alueisiin perustuva 
ymmärrys talouden ja yhteiskunnan toiminnasta, jossa muun ohella korostuu oletus markkinatoimijoiden yksiulotteisesta ja ennustettavasta käyttäytymisestä. Esimerkiksi verotuksen tason määrittämisessä tehdään oletuksia selkeästä ja lineaarisesta korrelaatiosta verotuksen tason ja taloudellisen aktiviteetin välillä. Usein näitä taustaoletuksia ei kuitenkaan ole kirjoitettu auki.

Näyttöperusteisen politiikan nousu nostaa esiin kaksi keskeistä kysymystä tutkitun tiedon ja politiikan suhteesta suomalaisessa yhteisöveropolitiikassa. 1) Millainen ja millä tieteenaloilla tuotettu tieto on muodostunut olennaiseksi veropoliittisessa lainvalmistelussa? 2) Kuinka tällainen tieto on viime kädessä välittynyt poliittiseen päätöksentekoon ja miten tutkittua tietoa on käytetty päätöksenteon tukena? Näihin kysymyksiin vastaaminen auttaa ymmärtämään, miten tiedontuotanto vaikuttaa poliittisen päätöksenteon polkuriippuvuuksiin ja eri politiikkavaihtoehtojen arvottamiseen.

\section{Oikeustieteestä taloustieteeseen - taloustiede 2010-luvun veropolitiikan tiedollisena perustana}

Veropolitiikan tiedontuotantoon osallistuvat Suomessa monet eri toimijat. Perinteisesti valtiovarainministeriön juristivetoinen vero-osasto on ollut vahva episteeminen keskus ja virkamiesvastuussa veropolitiikan valmistelusta. Valtiovarainministeriön ylin johto on kuitenkin ajoittain hyödyntänyt vero-osaston sijaan myös muita tiedontuotannon keskuksia. Etenkin Valtion taloudellisen tutkimuskeskuksen (VATT) rooli on kasvanut 2000-luvulla. ${ }^{6}$ Verotusta pohtineilla asiantuntijatyöryhmillä on ollut puolestaan merkittävää vaikutusta ideoiden ja näkökulmien tuottajina sekä keskustelun suunnan määrittäjinä. Eduskunnassa ja hallituksessa - erityisesti kehysriihien yhteydessä - veropolitiikan asialistaan vaikuttavat myös etujärjestöt. Lisäksi viimeaikaisessa tutkimuksessa on tuotu esiin huomioita verotutkijoiden ja verokonsulttien usein hyvin läheisistä suhteista (Raitasuo 2018 ja 2019). Tiedon ja politiikan välinen suhde suodattuu tämän monimutkaisen prosessin läpi veropolitiikkaan.

Vuosituhannen vaihteesta eteenpäin taloustieteellinen tieto on saanut aiempaa suuremman painoarvon suomalaista yhteisöverotusta valmistelevien työryhmien tiedontuotannossa. Oikeustieteellisen ammattikunnan edustajilla, 
ennen kaikkea oikeustieteen professori Kari S. Tikalla, oli aiemmin, erityisesti 1980-luvulta eteenpäin keskeinen rooli. Taloustieteen vahvistumisessa on ollut osittain kyse kansainvälisestä kehityskulusta, josta yhteisöverotus on vain yksi kuvaava esimerkki. Useat kansainväliset tutkimukset ovat kuvanneet paradigmaattista siirtymää, jossa uusklassisen taloustieteen merkitys on kasvanut julkishallinnon tiedontuotannossa (Christensen 2017; Fourcade, Ollion ja Yalgan 2015; Fourcade 2006). Suomeksi uusklassisen taloustieteen merkitystä yhteiskuntaa ohjaavana tietona ovat pohtineet esimerkiksi VillePekka Sorsa ja Teppo Eskelinen (Sorsa ja Eskelinen 2018).

Yritysverotuksen varsinainen käänne kohti taloustieteellistä tiedontuotantoa tapahtui vuoden 2005 verouudistuksen jälkeen. Tähän oli useita toisiinsa nivoutuneita syitä. Yhtenä keskeisenä syynä oli vaikutusvaltaisten juristien väistyminen. Heidän poistumansa loi episteemisen aukon, jonka taloustieteilijät täyttivät. Myös institutionaaliset tekijät (esimerkiksi näyttöperusteisuuden nousu politiikan ohjauksessa) tukivat taloustieteen merkityksen kasvua. Lisäksi voidaan havaita myös ulkopuolista painetta. Kansainväliset talousjärjestöt antavat maaraporteissaan suosituksia veropolitiikan uudistamiseksi. Koska varsinkin eurokriisin jälkeen tärkeissä valtion luottoluokitusten määrittelyssä (Paudyn 2013) ${ }^{7}$ seurataan valtion talouspolitiikan sopeutumista kansainvälisten talousjärjestöjen suosituksiin, suositusten noudattamisella on myös taloudellinen motiivi (Haastattelu 2019a). Näiden tekijöiden lopputuloksena Suomen veropolitiikassa voidaan havaita episteeminen murros, joka muutti juristien ja taloustieteilijöiden välistä suhdetta (Haastattelu 2019b).

Oikeustieteellisen ja taloustieteellisen tiedon ohjaamia yhteisöverouudistuksia on mahdotonta erotella mustavalkoisesti toisistaan. Jo 1990-luvun vaihteen verouudistukset, jotka koskivat myös yhteisöverotusta, perustuivat merkittäviltä osin Ronald Reaganin vuoden 1986 verouudistuksesta johdettuihin talouspoliittisiin ideoihin. Tätä laajempaa veropolitiikkaa ohjaavien ideoiden muutosta on tutkittu paljon kansainvälisesti (Campbell ja Pedersen 2014; Steinmo 2003). Kansainvälisesti nämä ideat perustuivat kiistellyille teorioille veronalennusten oletetuista, myönteisistä vaikutuksista taloudelliseen toimeliaisuuteen ja edelleen verokertymään (näistä teorioista ks. Mirowski 1982). Suomeen vastaavat ajatukset kulkeutuivat juristien välittämänä ja muita Pohjoismaita jäljittelemällä. Kuitenkin 2000-luvulla tiedontuotannossa 
ilmenevät argumentit sekä metodologiset valinnat saivat selkeästi vahvemman taloustieteellisen sävyn.

Siirtymä kohti vahvemmin taloustieteellistä tiedontuotantoa on muokannut näyttöperusteisuuden roolia veropolitiikan taustalla usealla tavalla. Ensiksi, ulkomaisten kansainvälisten tutkimusten merkitys tiedollisena lähteenä on kasvanut yhdessä näyttöperusteisen päätöksenteon kanssa. Toiseksi, verotuksen tehokkuuden ja neutraaliuden merkitys on vahvistunut edelleen muiden argumenttien kustannuksella. ${ }^{8}$ Tehokkuudesta ja neutraaliudesta puhuttaessa verotuksen kansalliset erityispiirteet jäävät huomiotta, mikäli verouudistusten oletetaan vaikuttavan samalla tavalla kansallisista toimintaympäristöistä ja poliittisista arvostuksista riippumatta. ${ }^{9}$ Kolmanneksi uusklassisesta taloustieteellisestä kirjallisuudesta johdetut taustaoletukset ovat jäsentäneet vaikutusarvioita tavoilla, joita suomalaisessa veropoliittisessa päätöksenteossa (tai julkisessa keskustelussa) ei aina ole ymmärretty. Näistä taustaoletuksista johdetut syy-seuraussuhteet ovat päätyneet ohjaamaan myös käytännön politiikkaa. Neljänneksi käytettävän tiedon ajallinen orientaatio on muuttunut. Siinä missä lainopillinen tulkinta on pääasiallisesti menneisyyteen katsovaa, taloustieteelliset vaikutusarviot suuntautuvat selkeästi tulevaisuuteen. Viidenneksi ja edelliseen huomioon liittyen, poliittista päätöksentekoa kehystävä asiatuntijatieto on alkanut yhä konkreettisemmin määrittää veropolitiikan sisältöä. Siinä missä oikeudellinen tieto ensisijaisesti osoittaa oikeusjärjestyksestä juontuvat juridiset ja systeemiset rajat, joissa päätöksenteon pitäisi liikkua, taloustieteellinen tieto vaikuttaa konkreettisemmin siihen, millaisia päätösten pitää olla, kun niillä halutaan päästä toivottuihin lopputuloksiin.

\section{Vuoden 1993 uudistus: reaganilaista veropolitiikkaa pohjoismaisiin tarpeisiin}

Vuoden 1993 verouudistus muovasi merkittävästi Suomen yritysverojärjestelmää. Vuosisadan verouudistuksena markkinoitu uudistus eriytti ansio- ja pääomatulojen verotuksen toisistaan. Lisäksi yhteisövero ja pääomatulovero yhdenmukaistettiin siten, että molempiin sovellettiin suhteellista 25 prosentin verokantaa, mikä laski nimellistä verokantaa sekä yhteisöjen tulon että pääomatulon verotuksessa huomattavasti. Uudistus oli osa 1980-luvulta 
alkanutta hallinnollista pyrkimystä verojärjestelmän suoraviivaistamiseksi. Sotien jälkeen Suomen yhteisöveropolitiikka oli vahvasti kytketty yleiseen talouspolitiikan strategiaan, jota ohjasi teollistuminen keynesiläisten periaatteiden mukaisesti. Tuotannollisiin investointeihin kannustaminen menikin monien muiden veropoliittisten päämäärien edelle. Tätä valtion aktiivista roolia talouden ohjaajana veropolitiikan kautta alettiin kyseenalaistaa 1980luvun puolivälin jälkeen niin akateemisissa kuin myös poliittisissa keskusteluissa. Tämän aikakauden keskeisimpänä vedenjakajana voidaan pitää Reaganin verouudistusta vuonna 1986.

Jo Holkerin vuoden 1989 kokonaisverouudistus korosti neutraliteettia verojärjestelmän keskeisenä tavoiteltavana piirteenä. Neutraliteetti tarkoitti tässä yhteydessä ennen kaikkea laajaa ja yhtenäistä veropohjaa, joka leikkaisi verotuksen ohjausvaikutusta esimerkiksi sijoitusten ja hankintojen kohdentumiseen, koska verokohtelu eri verotuskohteiden välillä olisi yhdenmukaisempaa. Yhteisöverotuksen osalta uudistamistarve kirjattiin vuonna 1991 myös Esko Ahon (kesk.) hallituksen ohjelmaan, minkä jälkeen valmistelu käynnistyi nopeasti.

Vuoden 1993 verouudistusta perusteltiin kahdella pääargumentilla, jotka todetaan verouudistuksen käynnistäneessä Ahon hallituksen ohjelmassa vuodelta 1991 (VNK 1991). Ensinnäkin tarkoituksena oli verotuksen ja ennen kaikkea pääomaverotuksen yhtenäistäminen. Suomen verojärjestelmä oli ennen uudistusta pirstaleinen ja lukuisten poikkeusten sekä verovähennysten leimaama. Tämä loi lukuisia mahdollisuuksia verokeinottelulle (Andersson 1994, 1; Haastattelu 2019b). Kun Suomen talous ajautui 1990-luvun alussa ongelmiin, verotuksen neutraliteetin lisääntymistä alettiin pitää tärkeämpänä talouden tehokkuuden ja verotuksen oikeudenmukaisuuden tukipilarina (Hjerppe, Kari, Rauhanen ja Ulvinen 2003; Turkkila 2011). Toiseksi, tarkoituksena oli Suomen verojärjestelmän muokkaaminen kansainvälisten pääomaliikkeiden tarpeisiin soveltuvaksi. Kansainvälisten pääomaliikkeiden vapautuminen sitoi Suomen yritysveropolitiikan liikkumavaran kiinteään suhteeseen kilpailijamaiden verotason kanssa. Erityisesti alueellinen verokilpailu alkoi tässä yhteydessä kiihtyä Pohjoismaiden kesken ja se on myöhemminkin ollut yksi Suomen veropolitiikkaa eniten ohjaavista tekijöistä.

Yhtenäistäminen ja kansainvälinen kilpailukyky olivat huomattavassa roolissa verouudistusta valmistelleessa asiantuntijaryhmässä (VM 1991). 
Työryhmää johti valtiovarainministeriön vero-osaston ylijohtaja Lasse Arvela. Sen muut jäsenet olivat Sixten Korkman, Edward Andersson, Kari S. Tikka, Heikki Niskakangas, Pauli K. Mattila, Mikael Ingberg ja Timo Viherkenttä. Työryhmä oli hyvin juristivetoinen, sillä jäsenistä vain Korkman ja Ingberg olivat ekonomisteja. Muut jäsenet olivat juristeja, vaikkakin Tikalla ja Niskakankaalla oli tutkintotaustaa myös taloustieteessä. Tämä asiantuntijaryhmä vaikutti merkittävästi Ahon hallituksen linjauksiin.

Työryhmän perustelu verotuksen yhtenäistämiselle perustui ajatukseen talouden tehokkuudesta. Raportin mukaan Suomessa oltiin "hiljalleen siirtymässä tilanteeseen, jossa pääomamarkkinat toimivat tehokkaasti. Toimivilla pääomamarkkinoilla sijoitusten tuotot ohjaavat pääomien allokointia. Tällaisessa tilanteessa yhtenäisen pääomatuloverotuksen tarve entisestään korostuu" (VM 1991, 5). Pertti Honkanen on pitänyt ajatusta verotuksen neutraliteetin lisäämisestä hyvän verojärjestelmän ominaisuutena vahvasti ideologisena (Honkanen 1993, 40). Neutraalisuusargumentti unohtuu esimerkiksi silloin, kun keskustellaan pääoma- ja työtulojen keskenään hyvin erilaisesta verotuksesta. Tehokkuuden korostaminen kuvastaa valtion yleisen roolin muuttumista talouspolitiikassa: valtioohjauksen sijaan taloudellisen toiminnan keskiöön asetettiin tehokkaaksi mielletty markkinamekanismi.

Työryhmän muistio vahvisti myös näkemyksen verokilpailukyvyn ja verotuksen yhtenäistämisen tarpeesta. Muistiossa todettiin, että " $[\mathrm{k}]$ ansainvälisten pääomaliikkeiden vapauduttua on entistä aiheellisempaa lähteä siitä, että verotus ei voi olennaisesti ylittää kansainvälistä tasoa" (VM 1991, 2). Toisin sanoen kansainvälisen verokilpailun nähtiin asettavan ylärajan kaikkein liikkuvimmille verotuskohteille, kuten pääomille sekä yrityksille (Jääskeläinen 1991; VM 1991, 8). Kilpailukykyargumentti näyttää perustuneen nimenomaan Norjan ja Ruotsin esimerkin seuraamiseen. Asiantuntijaryhmä totesi muistiossaan, että kansainvälisten trendien ennustaminen on epävarmaa. Se vaikuttaa kuitenkin olettaneen, että samanlainen pääoma- ja yhteisöveron laskutendenssi toteutuisi myös muissa Euroopan maissa Pohjoismaiden tavalla. Muistion mukaan "jopa Euroopassa on maita (esim. Luxemburg), joiden kanssa on miltei mahdoton kilpailla" (VM 1991, 6). Tämä korosti aikakaudelle tyypillistä verokilpailun (Steinmo 2003) ja laajemminkin 
systeemikilpailun kiihtymistä (Linsi 2019; Pedersen 2010). Myös Reaganin hallituksen esimerkki oli tärkeä (Haastattelu 2019b; Silfverberg 2013).

Vuoden 1993 uudistuksessa lainvalmistelun tiedontuotanto perustui lähinnä muiden Pohjoismaiden tekemien uudistusten selvittämiseen, vaikka tällaista vertailua pidettiinkin suhteellisen kapea-alaisena valmisteluna (Viherkenttä 2019). Samalla Pohjoismaiden vastaavista aloitteista omaksuttiin piirteitä. Uudistuksen vaikutuksia yritysten käyttäytymiseen ei tällöin arvioitu (VM 1991, 103 ja 105-107; ks. myös VM 1992, 7). Tämä kuvasti ajan henkeä. Vaikka verouudistus rakentuikin koeverolaskelmille, laskelmissa verovelvollisten käyttäytymisen ei oletettu muuttuvan verojärjestelmän uudistamisen seurauksena.

Vuoden 1993 uudistuksen jälkeen yhteisöverokanta nostettiin vuoden 1998 alusta 28 prosenttiin ja edelleen 29 prosenttiin vuoden 2000 alusta, samoin kuin pääomatulon verokanta. Yhteisöverokannan nostot heijastelivat vuoden 1993 uudistuksessa omaksuttua periaatetta, jonka mukaan yhteisöverokannan tuli seurailla pääomatulolle asetettua verokantaa. Vuosituhannen taitteessa yhteisöverokanta käännettiin uudelleen laskuun.

Juristivetoisen veropolitiikan lakipisteenä voidaan pitää vuoden 2002 Lasse Arvelan tuloverotyöryhmän raporttia, jossa myös Kari S. Tikka oli vielä mukana. Vuoden 2002 verotyöryhmän raportti oli poikkeuksellisen kansainvälinen, heijastaen lisääntyvää kiinnostusta kansainväliseen verojärjestelmien suunnitteluun. Suuri osa verotyöryhmän ehdotuksista linkittyi kansainvälisiin politiikkaprosesseihin ja kansallisen veropolitiikan reunaehtoihin, kuten OECD:n haitallisen verokilpailun hillitsemiseen tähtääviin hankkeisiin sekä Euroopan unionin oikeudelliseen kehitykseen verokysymyksissä. Talousteoreettinen päättely ja aineisto olivat tässä raportissa pienessä roolissa. Verotuottovaikutuksia arvioitaessa tukeuduttiin staattisille laskelmille, ja raportissa todetaankin, että verotuottovaikutusten "[n]umeerisissa arvioissa on kysymys karkeista arvioista, joissa ei ole otettu huomioon verotuottoihin vaikuttavaa kokonaistaloudellista kehitystä eikä ehdotettavien muutosten käyttäytymisvaikutuksia.” (VM 2002, 179). ${ }^{10}$

Pian verotyöryhmän raportin jälkeen tiedontuotannon tieteenalapohjassa tapahtui muutoksia. Edward Andersson oli eläköitynyt jo vuonna 1999, ja Tikka kuoli vuonna 2006. Tämä avasi episteemistä tilaa taloustieteilijäverotutkijoille, joita oli "merkittävästi paremmin, [kuin] aikanaan, jolloin 
taloustieteellinen verotutkimus oli enintään hyvin yleisellä tasolla”(Viherkenttä 2019). Kesällä 2019 eläköityneen eduskunnan verojaoston valiokuntaneuvos Maarit Pekkasen mukaan "nämä loistavat veroprofessorit poistuivat keskuudestamme, minkä jälkeen itse asiassa professorikunnassa tapahtui aika iso muutos. Näiden uudempien professoreiden fokus oli aika paljon kansainvälisessä vero-oikeudessa" (Pekkanen 2019). Samalla kun oikeustieteellinen tiedontuotanto antoi tilaa taloustieteelliselle tutkimukselle, nähtiin myös muutoksia vero-oikeuden tutkimuksen fokuksessa.

Näkyvien verojuristien väistyminen ei mullistanut suomalaisen veropolitiikan valmistelua täysin. Esimerkiksi valtiovarainministeriön veroosaston juristivetoista näkökulmaa tieteenalojen välisten painopisteiden muutokset eivät erityisesti heilauttaneet. Episteemisen painopisteen muutos ei myöskään näkynyt osastojen henkilöstömitoituksessa juurikaan. Olennaista kuitenkin on, että episteemisellä tieteenalamuutoksella oli merkittävä vaikutus verolakien valmistelua pohjustaneiden asiantuntijaryhmien kokoonpanoihin, suomalaisesta veropolitiikasta käytävään keskusteluun ja argumentteihin, joihin verouudistusten tiedollinen legitimiteetti nojasi. Nämä argumentit ovat luoneet polkuriippuvuuksia, jotka ovat jäsentäneet suomalaista veropolitiikkaa myöhemmin 2010-luvulla.

\section{Kohti vuoden 2014 verouudistusta}

Suomen yhteisöverotuksen yksi merkittävimmistä murroskohdista on Kataisen hallituksen vuoden 2014 verouudistus. Se laski yhteisöverokantaa kerralla 24,5 prosentista 20 prosenttiin, minkä lisäksi osinkoverotusta uudistettiin. Veronalennus oli jatkoa saman Kataisen hallituksen vuonna 2012 tekemälle uudistukselle, joka oli laskenut yhteisöverokantaa 26 prosentista 24,5 prosenttiin. Yhteensä Kataisen sixpack-hallitus laski yhteisöverokantaa neljän vuoden aikana siis kuudella prosenttiyksiköllä. Tämä oli suurin yhden hallituskauden aikana tehty yhteisöverokannan alentaminen 20 vuoteen (kuvio 1). 

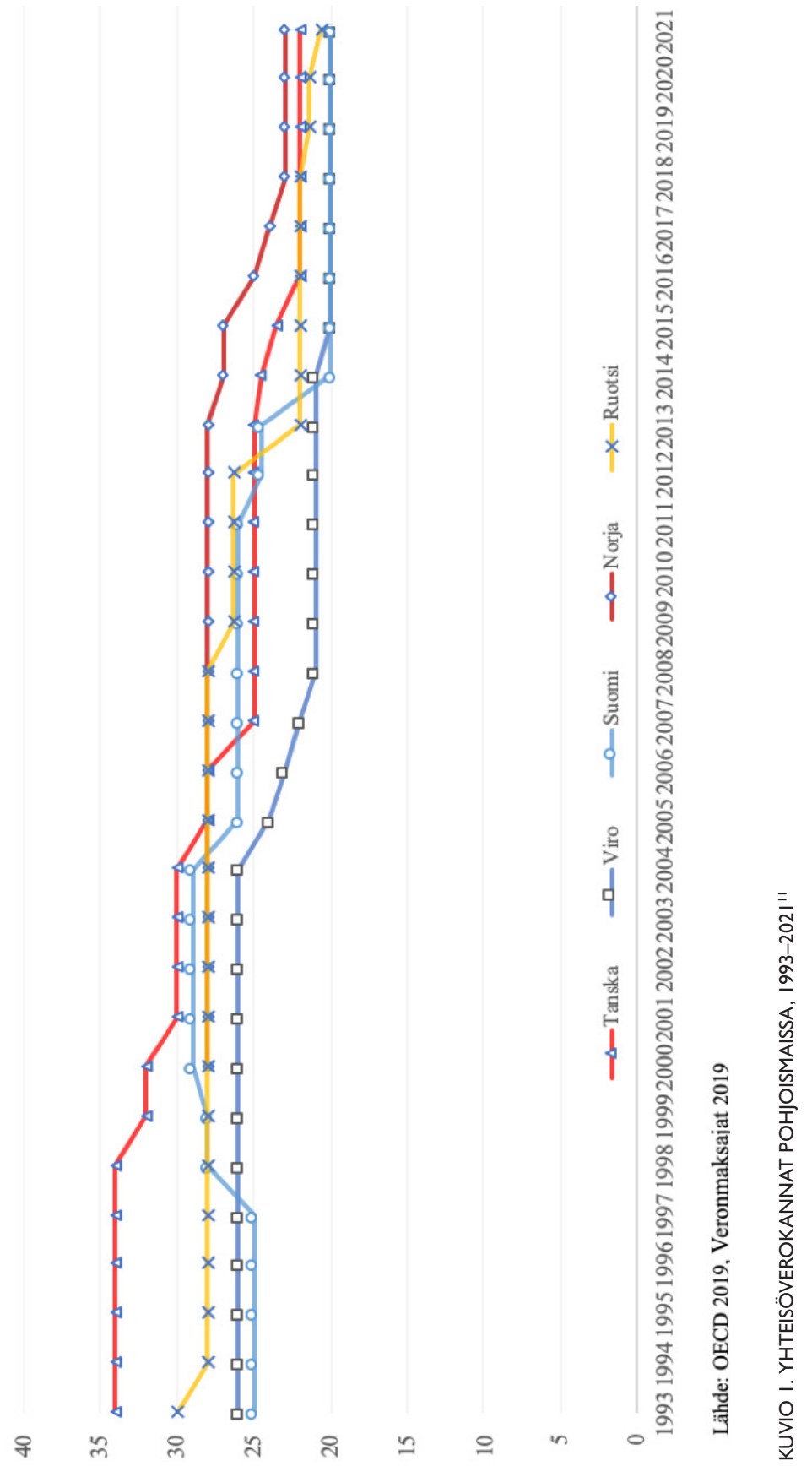
Verouudistusta perusteltiin Suomen talouden uudelleenkäynnistämisellä finanssikriisin jälkeisessä pitkittyneessä taloudellisessa taantumassa. Suomen talous oli jämähtänyt lyhyen palautumisen jälkeen alhaiselle kasvu-uralle. Talouskasvu oli painunut negatiiviseksi vuoden 2012 kaikkina vuosineljänneksinä, samalla kuin kilpailijamaat olivat jo alkaneet selvitä lamasta (Tilastokeskus 2019). Erityisesti Nokian ja Microsoftin irtisanomiset, teollisuuden rakennemuutos sekä kilpailukyvyn heikentyminen suhteessa kilpailijamaihin nähtiin tekijöinä, joiden vuoksi Suomen verojärjestelmästä täytyi tehdä yhä kilpailukykyisempi. Näissä olosuhteissa veropolitiikan nähtiin olevan yksi työkalu elvytyksen käynnistämiselle.

Jo Hetemäen johtaman verotuksen kehittämistyöryhmän vuoden 2010 väliraportti painotti kansainvälisen verokilpailun merkitystä Suomen kaltaiselle pienelle ja pääasiallisesti avoimelle taloudelle (VM 2010b, 72-73). ${ }^{12}$ Tämä verokilpailu oli luonteeltaan myös puolustuksellisesta: uusien yritysten houkuttelun lisäksi tavoitteena oli hidastaa monessa pohjoismaassa toimivien suuryritysten pääkonttorien siirtymistä muihin pohjoismaihin (Haastattelu 2019a). Alueellinen verokilpailu oli myös kiihtymässä, kun valtiot pyrkivät elvyttämään kansantalouksiaan veronalennuksin. Esimerkiksi Ruotsi oli tehnyt päätöksen yhteisöverokantansa laskemisesta 22 prosenttiin vuonna 2012. Viro oli poistanut yhteisöveron yrityksiltä, jotka jättävät voittonsa yritykseen. ${ }^{13}$ Tämän nähtiin luovan painetta vastaaville uudistuksille myös Suomessa.

Olosuhteet - talouden kriisitilanne ja alueellisen verokilpailun kiristyminen - olivat siis osin samankaltaiset kuin vuoden 1993 verouudistuksessa. Myös valitut toimenpiteet tuovat mieleen 1990-luvun alun: yritysten verotusta kevennettiin ja verorasitusta siirrettiin kohti vähemmän liikkuvia verotuskohteita. Lisäksi verotusta ehdotettiin kohdennettavaksi veropohjiin, jotka eivät reagoi herkästi verojärjestelmien eroihin. Verotuksen kehittämistyöryhmä korostikin, että verotuksen painopistettä voidaan siirtää yhtiöiden verotuksesta kohti yhtiöiden omistajien verotusta, koska pääomaverotus ei yhteisöverotuksen tavoin vaikuta Suomen kilpailukykyyn (esim. VM 2010b, 17). ${ }^{14}$ Tämä jakoi yritysten etujärjestökenttää. Yritysveron laskusta hyötyvät täysimääräisesti monikansalliset suuryritykset, mutta suomalaisomistuksessa olevien yritysten omistajien verotukseen vaikuttaa keskeisesti myös Suomen osinkoverotuksen taso (Haastattelu 2019c, 2019d). 
Joiltakin osin vuoden 2014 verouudistus oli jatkoa Suomen veropolitiikan keskeisille linjauksille, jotka olivat leimanneet veropolitiikkaa 1980-luvulta alkaen. Suuria uudistuksia on Suomen yhteisöveropolitiikassa yleensä tehty taloudellisen taantuman aikoina, ja niiden yhteydessä on ajettu näkemystä talouskasvun elpymisestä kevyemmän verotuksen myötä. Lisäksi vuoden 2014 uudistus tukeutui sitä edeltävien uudistusten rakenteellisille perusratkaisuille: suhteellisen matalalle yhteisöverokannalle, laajoille yhteisöveropohjille, pääosin eriytetylle tuloverojärjestelmälle ja vuonna 2005 omaksutulle osinkoverotusmallille. Jaetuista piirteistä huolimatta vuoden 2014 uudistus sisälsi kuitenkin myös uusia tapoja tiedon ja politiikan yhdistämiseksi. Kenties selvimmin tämä näkyy uudistuksen perusteluissa keskeisessä osassa olleissa oletetuissa käyttäytymisvaikutuksissa.

\section{Vuoden 2014 verouudistuksen valmistelu ja dynaamisten vaikutusten esiinmarssi}

Vuoden 2014 verouudistuksen valmistelu alkoi loppuvuodesta 2012. Se käynnistettiin ensin valtiovarainministeriön ulkopuolella, VATTin sekä valtiovarainministeriön johdon yhteistyönä (Kortela ja Maunu 2014a). Valtiontalouden tarkastusviraston haastattelumateriaalien mukaan tieto tulevasta osinko- ja yhteisöverouudistuksesta saapui valtiovarainministeriöön joulukuussa 2012. Seuraavaksi valmistelu jatkui julkisuudessa maaliskuun alussa, kun valtiovarainministeriö ja VATT toimittivat laskelmia hallituksen valtiontalouden kehyspäätöksen valmistelun tueksi ennen kehysriihipäätöstä. Prosessi kulminoitui vuoden 2013 kehysriihipäätökseen, jossa julkistettiin tulevat uudistukset.

Valmisteluprosessissa oli monta uutta piirrettä. Esimerkiksi työnjako poikkesi aikaisemmista verouudistuksista, joissa valmistelu oli tapahtunut pitkälti valtiovarainministeriön sisällä ja valmisteluaikaa leimasi kiire ja prosessin hajanaisuus (VTV 2014, 46). Eniten keskustelua herätti kuitenkin yhteisöveronalennuksen dynaamisten vaikutusten mukaanotto. Dynaamisilla vaikutuksilla tarkoitetaan verojärjestelmän muutoksen vaikutusta taloudellisten toimijoiden käyttäytymiseen. Aikaisemmin veromuutosten yhteydessä oli tehty pelkästään staattisia laskelmia. Toisin sanoen niissä oletettiin, että veronalennus ei muuta 
taloustoimijoiden käyttäytymistä. Dynaamiset vaikutukset edellyttävät staattisia vaikutuksia syvällisempiä teoreettisia oletuksia taloudellisten prosessien syy-seuraussuhteista. Vuoden 2014 verouudistuksessa käyttäytymismuutosten oletettiin johtavan talouden kasvuun niin, että verouudistus rahoittaisi itsensä merkittäviltä osin takaisin. Näiden vaikutusten suuruudeksi arvioitiin kehyspäätöksen valmistelussa ja lopullisessa kehyspäätöksessä jopa 50 prosenttia. (VM 2013, 30-31.) Niillä oli keskeinen rooli verouudistuksen perusteluissa ja kehyspäätöksen lopputulemassa.

Dynaamisten vaikutusten mukaanotto oli poikkeuksellista, sillä Suomen yhteisöveropolitiikan historiassa käyttäytymisvaikutuksia ei ollut aikaisemmin otettu huomioon tässä laajuudessa. Taloustieteellisesti orientoituneessa Hetemäen verotuksen kehittämistyöryhmän raportissakin (VM 2010c, 31) kirjoitetaan lähinnä kvalitatiivisista dynaamisista vaikutuksista eikä niinkään määrällisistä vaikutuksista. Raportissa viitataan yleisluontoisiin lainalaisuuksiin, joita verojärjestelmämuutosten ja taloudellisen käyttäytymisen välillä on tunnistettu tutkimuksessa, mutta verojärjestelmään ehdotettujen muutosten tuotto- ja tulonjakovaikutukset arvioidaan edelleen staattisen laskentaperinteen mukaisesti. Vuoden 2014 arvioita pidettiin julkisessa keskustelussa epävarmoina ja niiden soveltuvuus suomalaiseen toimintaympäristöön kyseenalaistettiin. (Hyytinen 2015; Silfverberg 2013; Raeste 2013; Rantanen ja Suominen 2013; Yle 2013a, Yle 2013b.) Dynaamiset vaikutukset olivat myös ristiriidassa valtiovarainministeriön perinteisen toimintakulttuurin kanssa, jossa dynaamisia vaikutuksia oli pidetty "tutkijoiden hölynpölynä" (Haastattelu 2019e). Vuoden 2014 verouudistuksessa dynaamiset vaikutukset huomioitiin lisäksi pelkästään yhteisöveron osalta.

Dynaamisten vaikutusten mukaanotolle on esitetty lukuisia erilaisia selityksiä. Yksi perustelu on pragmaattinen. Verotuksen taloustieteen yksi keskeisimpiä havaintoja on ollut, että verotus muuttaa verovelvollisten käyttäytymistä. Näiden havaintojen perusteella dynaamisten vaikutusten huomioimatta jättämistä pidettiin parhaan tutkitun tiedon vastaisena, jopa virkavelvollisuuden rikkomisena, varsinkin kun muilla politiikka-aloilla tällaisia käyttäytymisvaikutuksia otetaan säännönmukaisesti huomioon. (Haastattelu 2019a, 2019b.) Toisekseen, poliittinen tilanne oli otollinen dynaamisten vaikutusten mukaanotolle. Talouden heikko kehitys oli johtanut tarpeeseen keksiä uusia keinoja kasvun löytämiseksi. Tässä yhteydessä yhteisöveroleikkaukset 
tuotiin poliittiseen keskusteluun yhtenä mahdollisena mekanismina. Erityisesti sosialidemokraattisen puolueen johdolle yhteisöveron alennus oli poliittisesti herkkä kysymys, sillä se oli epäsuosittu puolueen kannattajien piirissä. ${ }^{15}$ Konkreettiset vaikutusarviot helpottivat päätöksen poliittista perustelua. (Kiander teoksessa Rantanen ja Suominen 2013, Haastattelu 2019f.)

Vaikka julkinen keskustelu dynaamisista vaikutuksista oli kriittistä, ei arvioiden alkuperää ole ennen tätä artikkelia avattu kunnolla julkisuudessa ja aiheesta on keskusteltu vain melko yleisellä tasolla. Haastattelujemme ja asiakirjalähteiden mukaan olettama yhteisöveron dynaamisista vaikutuksista pohjautui Ruud de Mooijin ja Sjef Ederveenin kansainvälisen verotaloustieteen katsausartikkeliin (2008). Artikkeliin viitataan myös edellä mainitussa Valtiontalouden tarkastusviraston raportissa (VTV 2014, 22-24) sekä talouspolitiikan arviointineuvoston raportissa (Talouspolitiikan arviointineuvosto 2014, 104-105). Myös useampi haastateltavamme vahvisti toisistaan riippumatta artikkelin merkityksen. Haastattelujemme mukaan artikkelia käsiteltiin poikkeuksellisesti virkamiesvalmistelun lisäksi myös korkeimmalla poliittisella tasolla ja artikkeli oli jopa mukana neuvottelijoiden salkuissa kehysriihen aikana (Haastattelu 2019f). Katsausartikkelin voidaankin sanoa olleen poikkeuksellisen merkittävä yksittäinen tietolähde veropoliittisessa valmistelussa.

Yhteensä 427 eri maata ja talousaluetta koskevan taloustieteellisen artikkelin tutkimustuloksiin perustuen de Mooij ja Ederveen (2008) arvioivat, että yritysveron alennukset laajentavat veropohjaa. Tämä voi tapahtua artikkelin mukaan viiden eri mekanismin välityksellä: muutokset yritystoiminnan oikeudellisessa muodossa; siinä, millä lainkäyttöalueella kansainväliset yritykset raportoivat voittonsa; velan ja oman pääoman suhteessa; yksittäisissä maissa tehtyjen investointien koossa sekä näiden määrässä. Yhteisöveron laskun vaikutus kuhunkin mekanismiin arvioitiin ekonometrisin menetelmin aiemman empiirisen tutkimuksen meta-analyysilla. Artikkelin johtopäätöksenä todetaan, että veroprosentin laskiessa yhdellä prosentilla veropohja kasvaa taloudellisen toiminnan lisääntymisen myötä keskimäärin 3,1 prosenttia. Tämän artikkelin perusteella uudistuksen valmistelijat totesivat, että Suomen 4,5 prosenttiyksikön verokannan alennus johtaisi veropohjan laajentumiseen niin, että teoreettinen itserahoitusaste olisi 62 prosenttia.

Artikkeliin sisältyy useita huomionarvoisia taustaoletuksia ja rajauksia, jotka hahmotettiin verouudistuksesta käydyssä julkisessa keskustelussa huonosti tai 
ei lainkaan. Ensinnäkin, veropohjan laajeneminen ei pääasiallisesti seuraa siitä, että reaalinen taloudellinen toiminta lisääntyisi. Artikkelin mukaan jopa kaksi kolmasosaa dynaamisista vaikutuksista seuraa kansainvälisten yritysten verosuunnitteluratkaisujen tai jo olemassa olevan taloudellisen toiminnan oikeudellisen muodon muutoksista. Toisin sanoen yritysten ajatellaan näyttävän voittonsa mieluiten alhaisen yhteisöverotuksen maissa. Nämä muutokset ovat herkkiä vastaaville veromuutoksille muissa maissa, minkä seurauksena yhdessä valtiossa saavutettu verotulojen kasvu voi nollautua muiden valtioiden politiikkatoimilla. Pitkäkestoiset taloudelliset vaikutukset ovat artikkelin mukaan vähäisiä, kuten myös Talouspolitiikan arviointineuvosto $(2015,104)$ on jälkikäteen todennut. Valtaosassa vaikutuksista ei kyse olekaan todellisesta taloudellisen toiminnan syntymisestä, kuten esimerkiksi työllisyyden lisääntymisestä, vaan kirjanpidollisluonteisista siirroista.

Huomattavaa on, että edes kansainvälisten yritysten verosuunnittelun ja yhteisöveron tason välinen suhde ei ole niin yksiselitteinen kuin artikkelissa oletetaan. Monien de Mooijin ja Ederveenin lainaamien tutkimusten pohjalla oleva data on hyvin puutteellista. Erityisesti tiedonsaannin mahdottomuus veroparatiiseista vääristää merkittävästi yritysten tilinpäätöstietokantojen perusteella tehtyjä taloustieteellisiä puolijoustotutkimuksia. Lisäksi tilastoaineistoissa ei esimerkiksi eritellä kiinteitä toimipaikkoja, jotka näkyvät tilinpäätöstilastoissa eri maan tulona kuin verotuksessa, jossa niitä käsitellään erillisinä yksikköinä. (Clausing 2016; Finér ja Ylönen 2017; Tørsløv, Vier ja Zucman 2018.) Tästä syystä niistä johdetut arviot ovat erittäin epävarmoja, mikä tyypillisesti sivuutetaan alan taloustieteellisessä tutkimuksessa. Yhteisöverokanta ei myöskään ole kansainvälisten yritysten verosuunnittelun ainoa tai edes tärkein muuttuja. Todellisuudessa yritysten verosuunnittelurakenteisiin vaikuttavat lukuisat monimutkaiset tekijät, joista verotukseen liittyvinä voidaan mainita sijoittumisen kannalta relevantit verosopimukset, verotuksen aukot ja verotuksen hallinnollinen tehokkuus (esimerkiksi Anguelov 2015; Klemm ja Van Parys 2009; Marr ja Huang 2014).

Lisäksi de Mooijin ja Ederveenin kuvaaman kansainvälisen voittojen siirron laajuuteen voidaan vaikuttaa merkittävästi aggressiiviseen verosuunnitteluun puuttuvalla lainsäädännöllä ja sen tehokkaalla toimeenpanolla. Tämä puoli jäi de Mooijin ja Ederveenin tutkimuksessa vaille huomiota. Esimerkiksi Suomessa vuonna 2014 käyttöön otettu korkovähennysrajoitus lisäsi yhteisöverotuloja 
merkittävästi siitäkin huolimatta, että esitys ei lopettanut konsernin sisäisillä lainoilla tehtävää aggressiivista verosuunnittelua (Kauppinen, Harju ja Ropponen 2017). Monet vuoden 2014 uudistuksen taustalla vaikuttaneet asiantuntijat tiedostivat kansainvälisen voittojen siirron merkityksen dynaamisia vaikutuksia koskevassa kansainvälisessä tutkimuksessa. Sekä Verohallinnon että joillakin valtiovarainministeriön virkamiehillä oli suurpiirteinen käsitys yritysten siirtohinnoittelu- ja korkovähennyskäytännöistä, joita koskevan tiedon perusteella dynaamisten vaikutusten suuruusluokka katsottiin mahdolliseksi arvioida. (Niskakangas 2019.) Kuitenkin joidenkin haastateltujen mukaan uudistuksen valmistelijoillakin ja erityisesti poliittisella johdolla oli merkittävää epävarmuutta siitä, mikä oli uudistuksen tiedollinen perusta.

Näitä artikkeliin liittyviä epävarmuuksia ja puutteita ei hahmotettu kunnolla aiheesta käydyssä julkisessa keskustelussa. Artikkelista johdettavia politiikkasuosituksia tehtiin melko suurpiirteisesti, ja esimerkiksi VATTin tutkijoiden teknisiin taustamateriaaleihin kirjaamat epävarmuudet (Kari ja Ropponen 2014, 18-20) käytännössä sivuutettiin julkisessa keskustelussa. Yhtenä esimerkkinä voidaan pitää 50 prosentin itserahoitusasteen käyttöönottoa, jota pidettiin käytännöllisenä heuristiikkana, joka ottaisi huomioon päätökseen liittyvät epävarmuudet (Kortela ja Maunu 2014a, Haastattelu 2019b). Kehyspäätökseen kirjattiin artikkelissa mainitut vaikutusmekanismit. Siinä jätettiin kuitenkin mainitsematta, että työllisyyden ja pitkän aikavälin talouskasvun kannalta merkittävimpiin tekijöihin liittyvät dynaamiset vaikutukset olivat tehdyn ennusteen mukaan huomattavasti pienempiä kuin lyhytaikaiset, kirjanpidollisluonteiset siirrot. Näitä tekijöitä ovat esimerkiksi työpaikkoja luovien investointien määrä ja koko. Myöskään uudistuksen vaikutuksia esimerkiksi varallisuuden keskittymiseen ei mainittu tai arvioitu.

Dynaamiset vaikutukset eivät lopulta päätyneet hallituksen esitykseen. Tälle on esitetty useita eri selityksiä. Ensinnäkin kehyspäätös ja hallituksen esitys ovat virkamiesten mukaan laadullisesti erilaisia. Siinä missä hallituksen esityksessä ollaan reaalimaailmassa, kehyspäätöksessä näkemyksiä on mahdollista esittää "voidaan ajatella" -tyyppisesti. Tästä erosta johtuen myös tiedon tarpeet ovat erilaiset. (Maunu ja Kortela 2014a.) Lähtökohtaisesti hallituksen esityksissä käytetään staattisia, varmempia vaikutuksia, mutta kehyspäätöksessä voidaan esittää myös veropolitiikan muutoksen "odotetut ja toivotut vaikutukset" (Maunu 2014). Taustalla ovat myös käytännölliset syyt: koska dynaamisten 
vaikutusten arviointi on epävarmaa, niitä ei haluta kirjata eksplisiittisesti hallituksen esitykseen, sillä se pakottaisi lisäämään ne budjetointisuunnitelmaan joka verovuodelle erikseen. Kolmanneksi myös poliittinen tilanne ja julkinen keskustelu saattoi edesauttaa dynaamisten vaikutusten katoamista. Toisaalta dynaamisiin vaikutuksiin kohdistui lopulta julkisessa keskustelussa huomattavaa kritiikkiä, mistä syystä niiden ottaminen mukaan saattoi muodostua vaikeammaksi poliittisen prosessin edetessä ja dynaamisten vaikutusten tultua kyseenalaistetuksi (Haastattelu 2019a). Dynaamisten vaikutusten katoaminen ei kuitenkaan vaikuttanut yhteisöveron alennuksen määrään. 20 prosentin yhteisöverokanta astui voimaan 1. tammikuuta 2014, huolimatta kustannusten kaksinkertaistumisesta. Kirjoittamishetkellä tämä on edelleen voimassa oleva yhteisöverokanta.

\section{Verotuksen asiantuntijatyöryhmät, tiedontuotannon murros ja talouden ennustamisen ongelmat}

Näyttöperusteisuuden merkitys on kasvanut 2000-luvulla samalla, kun suomalaisen yhteisöveropolitiikan tiedontuotannon perusteet ovat muuttuneet. Oikeustieteellisesti virittyneestä tiedontuotannosta on kallistuttu taloustieteelliseen tiedontuotantoon, mikä on johtanut taloustieteessä usein epäsuorasti läsnä olevien normatiivisten ja kausaalisten oletusten vakiintumiseen osaksi politiikantekoa. Tämän siirtymän pohjalta voidaan tehdä kolme laajaa alustavaa havaintoa, jotka liittyvät yhteisöverotuksen tiedontuotannon historialliseen muutokseen.

Ensinnäkin, valtavirran taloustieteestä johdetut argumentit tulivat Suomeen 1990-luvun vaihteessa vertailumaissa tehtyjen uudistusten inspiroimina, ja ne pohjautuivat näiden uudistusten taustalla olleisiin taloustieteellisiin ideoihin. Suomalaisen yhteisöveropolitiikan taustalla vaikutti kuitenkin juristien vetämä valmistelu ja tiedontuotanto. Toiseksi, oikeustieteelliseen argumentaatioon nojaava tiedontuotanto alkoi heikentyä vuoden 2005 verouudistuksen jälkeen. Merkittävien verojuristien poistuma ja samanaikainen, osittain kansainvälisten organisaatioiden painottama näyttöperusteisen tiedontuotannon vahvistuminen toi ekonomistiset argumentit aiempaa vahvemmin suomalaisen yhteisöveropolitiikan valmisteluun. Valmistelun taustalla olevat oletukset 
erilaisista syy-seuraussuhteista pohjautuivat aiempaa vahvemmin uusklassisen taloustieteen lähtökohtiin. Kolmanneksi, oikeustieteellisen ja taloustieteellisen tiedontuotannon muuttunut tasapaino loi olosuhteet, joissa talousteoreettisiin taustaoletuksiin perustuvat dynaamiset laskelmat tulivat keskeiseksi osaksi suomalaista veropolitiikan valmistelua vuonna 2013.

Tiedontuotannon polkuriippuvuuksien näkökulmasta on tärkeää korostaa verotusta suunnitelleiden työryhmien merkitystä suomalaisen veropolitiikan muovautumiselle. Jo vuoden 1993 uudistus nojasi vahvasti yhden juristipohjaisen asiantuntijatyöryhmän ehdotuksiin. Ryhmän työ perustui kansainvälistä vaikutusvaltaa saaneisiin talouspoliittisiin- ja verojärjestelmän rakennetta koskeviin ideoihin, ja se pyrki rakentamaan uudelleen verojärjestelmän kantavat rakenteet. Tämä korosti kokonaisvaltaisen ja oikeudellis-systeemisen tiedon merkitystä valmistelussa, koska muutokset koskivat lähes koko verojärjestelmää. Uudistusta olisi ollut mahdotonta tehdä ilman kattavaa käsitystä uudistuksen vaikutuksista verojärjestelmän eri alueilla. Poliittista päätöksentekoa ohjaavan tiedontuotannon näkökulmasta kiinnostavaa on, että työryhmän ehdotukset menivät läpi valiokunnissa ja eduskunnassa lähes sellaisenaan (Heino 2015).

Myös vuoden 2002 työryhmä oli vahvasti juristivoittoinen. Yksi työryhmän merkillepantavimmista piirteistä oli kansainvälisen oikeuskehityksen painoarvo sen työssä. Suomi oli liittynyt Euroopan unioniin vuonna 1995, ja Arvelan työryhmässä käsiteltiin laajalti esimerkiksi Euroopan unionin oikeuden tuomia paineita suomalaiselle verolainsäädännölle, kuten osinkoverosääntelylle. Myös OECD:n haitallisen verokilpailun vastainen aloite ja EU:n yritysverotuksen käytännesääntötyöryhmän työ sai huomiota. Suomen verokilpailukykyä parantavia strategioita tarkasteltiinkin suhteessa siihen, millaiset verokilpailukeinot olivat hyväksyttyjä OECD:n ja EU:n oikeudellisessa kehyksessä. Kansainvälisoikeudellista ja eurooppaoikeudellista taustaa vasten mataliin verokantoihin perustuvan verokilpailustrategian katsottiin olevan varsin hyvin sopusoinnussa haitallista verokilpailua koskevan ylikansallisen sääntelyn kanssa (VM 2002, 38).

2010-luvun veropolitiikassa keskeinen rooli on ollut valtiovarainministeriön alivaltiosihteeri Hetemäen verotyöryhmän raporteilla. Vanhasen II hallitus asetti työryhmän vuonna 2008 pohtimaan veropolitiikan uudistuksia. Raportit valmistuivat 2010 - väliraportti ensin kesäkuussa ja loppuraportti joulukuussa 
- ja ne toimivat pohjaesityksenä tulevalle uudistukselle. Hetemäen työryhmä erosi merkittävästi aiemmille verouudistuksille suuntaa antaneista asiantuntijaryhmistä. Työryhmä oli ekonomistivoittoinen, ja vielä selvemmin ekonomistisen tiedontuotannon vahva rooli näkyi raportissa käytetyissä tietolähteissä. Viittaukset painottuivat vahvasti kansainvälisissä kansantaloustieteen lehdissä julkaistuun verotutkimukseen. Silloin kun kansainvälisiin järjestöihin viitattiin, oli kyse yleensä niiden ekonomistiosastojen tuottamista raporteista ja tutkimuksista. Kuten alla osoitamme, käytettiin niitä myös valikoiden. Vuoden 2002 raporttia luonnehtinut juridinen ote kansainväliseen sääntelyyn pääosin puuttui. Tämän sijaan raporteissa pyrittiin ottamaan aikaisempaa rohkeammin kantaa myös veromuutosten oletettuihin, ennen kaikkea laadullisiin seurauksiin.

Verotyöryhmän akateeminen painotus näkyi myös aktiivisena panostuksena akateemiseen julkaisutoimintaan raportin yhteydessä. Eräs haastateltava korosti myös molemminpuolista tiedonvaihtoa Mirrlees Review'n tekijöiden kanssa (Haastattelu 2019b). Juuri Hetemäen työryhmän raportit loivat viitekehyksen 2010-luvun veropolitiikalle sekä verotusta koskevien talousteoreettisten argumenttien tuomiselle lainvalmisteluun vuonna 2013. Myös VATT:in kvantitatiivista osaamista käytettiin valmistelussa. VATT on tunnettu käyttämästään osittaisen tasapainon VATTAGE-mallista. Kyse on yleisen tasapainon teorian mukaisesta mallista, joka rakentuu kansantalouden tilinpidon tiedoista koostuvasta tietokannasta ja lukuisista talousteoreettisista käyttäytymisoletuksista. (Honkatukia 2009; Honkatukia ja Ahokas 2012.) Näiden mukaan esimerkiksi yritykset pyrkivät aina maksimoimaan voittojaan, eikä niiden investointipäätöksissä oteta huomioon keinotekoisen kansainvälisen voitonsiirron mahdollisuuksia: esimerkiksi tuotteiden hinnoittelun oletetaan perustuvan marginalistiseen hyötyanalyysiin (Honkatukia 2009, 14). VATTAGEmallin käyttöä on lisännyt sen kehittäjien mukaan juuri kvantitatiivisen politiikka-analyysin kasvanut kysyntä (Honkatukia 2009, 1). Kansainvälisesti tällaisten mallien suosiota on siivittänyt niitä hyödyntävien helppokäyttöisten tietokoneohjelmien kehitys (Honkatukia 2009, 4).

Kysymys ennustemalleista kytkeytyy laajemmin käyttäytymisvaikutusten ennustamisen mahdollisuuteen. Tässä suhteessa Valtiontalouden tarkastusviraston ja talouspolitiikan arviointineuvoston jälkikäteiset eriävät näkemykset dynaamisten vaikutusten mukaanotosta vuonna 2014 ovat kiinnostavia. 
Talouspolitiikan arviointineuvosto toteaa, että dynaamiset vaikutukset tulisi niiden epävarmuuden vuoksi poistaa lainvalmistelusta, varsinkin hallituksen esityksistä, ja pitäytyä pelkästään lakimuutoksen staattisten vaikutusten arvioinnissa. (Talouspolitiikan arviointineuvosto 2014, 105.) Talouspolitiikan arviointineuvoston käsityksestä voidaan päätellä, että se näkee dynaamisten vaikutusten käyttämisen lainvalmistelussa ylipäätään ongelmallisena. Valtiontalouden tarkastusviraston näkökulmasta dynaamisia vaikutuksia olisi pitänyt päinvastoin korostaa enemmän ja ne olisi tullut säilyttää myös hallituksen esityksessä (VTV 2014, 26). Valtiontalouden tarkastusviraston mukaan ratkaisu ennustamisen epävarmuuksien vähentämiseen on siirtyminen makrotaloustieteessä suosiota saaneiden, laajempien stokastisten yleistasapainomallien eli DSGE-mallien (dynamic stochastic general equilibrium model) käyttöön käyttäytymisvaikutusten arvioinnissa. Valtiontalouden tarkastusviraston käsityksen mukaan dynaamisilla vaikutuksilla tulisi olla keskeinen asema lainvalmistelussa, mutta niiden laskemisessa tulisi käyttää yhä monimutkaisempia ja hienostuneempia menetelmiä. ${ }^{16}$

Nämä eriävät mielipiteet kuvaavat laajemmin ennusteiden tekemiseen liittyvää ongelmakenttää. Mark Blyth (2011) on nimittänyt taloustieteellisissä ennustemalleissa käytettyjä taustaoletuksia ELEN-paradigmaksi. Tässä paradigmassa todellisuuden oletetaan pyrkivän kohti tasapainoa, kausaalisuuden olevan lineaarista sekä ajassa vakaata, yhteiskunnassa tapahtuvan muutoksen johtuvan ulkoisista syistä ja yhteiskunnallisten asiaintilojen olevan normaalijakautuneita. Toisin sanoen suurten poikkeamien oletetaan olevan harvinaisia (Blyth 2011, 84-87). Nämä oletukset tekevät periaatteellisella tasolla mahdolliseksi kvantitatiivisten piste-ennusteiden tekemisen ja politiikkatoimien syy-seuraussuhteiden ennakoimisen valitun selityskehikon puitteissa. Näin tehdyt ennusteet ovat kuitenkin herkkiä valitulle näkökulmalle, empiirisessä tarkastelussa valituille ekonometrisille parametreille ja implisiittisille oletuksille syy-seuraussuhteista. Juuri näiden taustaoletusten kriittinen tarkastelu on silti hankalaa. Syvällinen perehtyminen päätöksenteon taustalla olevaan ekonometriseen tutkimukseen edellyttää aikaa ja resursseja, joita poliittisessa prosessissa tai virkamiesvalmistelussakaan harvoin on. Näin poliittisessa päätöksenteossa joudutaan luottamaan enemmän tai vähemmän sokeasti valmistelumateriaaliin, mikä kasvattaa tiedontuotannon valtaa suhteessa politiikkaan. 
Tämänkaltaiset teoreettiset keskustelut taloustieteellisen ennustamisen mahdollisuudesta olivat vielä 1990-luvulla vähemmän relevantteja suomalaiselle veropoliittiselle keskustelulle. Niistä käytävän keskustelun tärkeys on korostunut, koska taloustiede on 2010-luvulla täyttänyt episteemistä aukkoa, jonka vaatimus politiikan näyttöperusteisuudesta on synnyttänyt. Perustavanlaatuiset keskustelut taloudellisen toiminnan luonteesta ovat välittyneet Suomeen erityisesti verotyöryhmien raporttien, valmisteluprosessissa käytettyjen taustamateriaalien ja organisaatiokulttuuristen muutosten myötä. Vaikka tiedontuotannon taustalla voidaan nähdä vilpitöntä pyrkimystä sitoa päätöksentekoa parhaaseen saatavilla olevaan tietoon, tehdään valmistelussa toisinaan kuitenkin implisiittisesti kyseenalaisiakin oletuksia yhteiskunnallisista syy-seuraussuhteista ja taloudellisen toiminnan luonteesta. Nämä teoreettiset ennakko-oletukset luovat viitekehyksen, jonka sisällä päätöksentekijät hahmottavat syy-seuraussuhteita ja tekevät päätöksiä monimutkaisessa toimintaympäristössä (Campbell ja Pedersen 2014, 3; Haas 1992). Näin kiistanalaisistakin oletuksista saattaa tulla osa veropolitiikan mahdollisuuksia rajaavaa tiedollista viitekehystä.

\section{Ideoiden politiikka ja näyttöpohjainen päätöksenteko: huomioita ja suuntaviivoja tulevaan}

Olemme tässä artikkelissa kuvanneet, kuinka taloustieteellinen tieto nousi 2010-luvulla aiempaa keskeisempään asemaan yhteisöveropolitiikan valmistelussa. Tätä muutosta voidaan tarkastella ainakin kolmesta näkökulmasta. Ensinnäkin voidaan kysyä, onko taloustieteellisen tiedon lisääntyminen tarkoittanut muiden tiedollisten näkökulmien, kuten aiemmin hallitsevassa asemassa olleen oikeudellisen tarkastelun, painoarvon vähenemistä valmistelussa. Tämä liittyy myös kysymykseen erilaisten tiedontuotannon muotojen kattavuudesta lainvalmistelun kokonaisuudessa. Toiseksi voidaan kysyä, onko taloustieteellisen tiedon merkityksen lisääntyminen kaventanut poliittisen tahdonmuodostuksen liikkumatilaa teknokraattisen asiantuntijatiedon hyväksi. Kolmanneksi voidaan tarkastella, missä määrin taloustieteellisen tiedontuotannon taustaoletukset kaventavat lainvalmistelun tiedollista pohjaa. Suomalaisessa yhteisöveropolitiikassa taloustieteellisen tiedon asema on 
vahvistunut näyttöperusteisen politiikanteon myötä. Myös yksittäisten asiantuntijoiden ja asiantuntijainstituutioiden asemassa tapahtuneet muutokset ovat olleet merkittäviä.

Politiikan kannalta kulloinkin relevanttina pidetty tieto on sidoksissa siihen, millaisia poliittisia muutoksia tehdään. Esimerkiksi 1990-luvun radikaalit rakenteelliset muutokset verojärjestelmässä edellyttivät oikeusjärjestelmän laajaa rakenteellista ja systeemistä tuntemusta. Toisaalta vuoden 2014 yhteisöverokannan madaltaminen oli yksinkertaisempi, vaikkakin radikaali politiikkatoimi, joka muovasi vähemmän verojärjestelmän kokonaisuutta. Lisäksi oikeustieteellisen ja taloustieteellisen tiedon näkökulmasta on kiinnostavaa, millainen näiden tiedonmuotojen suhde politiikkaan ja hallintoon on perinteisesti ollut. Oikeustiede on klassisesti ollut hyvin käytännönläheinen tiede: oikeustieteessä tutkimuksen valtavirran käytännöt eivät useinkaan ole merkittävästi eronneet niistä asiantuntijatiedon käytännöistä, jotka ovat olleet läsnä julkisessa hallinnossa ja lainvalmistelussa juridisen koulutuksen saaneiden virkamiesten myötä. Tällaisena oikeudellinen tieto on mukana lainvalmistelun useissa eri vaiheissa.

Eri tieteenalojen välisen painoarvon lisäksi tapaustutkimuksemme herättää kysymyksiä, jotka koskevat nimenomaisemmin politiikan ja asiantuntijavallan välistä suhdetta. Yhtäältä uudenlaisen vuoropuhelun löytäminen päätöksenteon, hallinnon ja tutkimuksen välillä on nähty yhtenä lääkkeenä demokratian murrokseen, kun tiedontuotanto on demokratisoitunut ja kokemuksellinen tieto on noussut osaksi poliittisten päätösten valmistelua (Lähteenmäki-Smith ja Kuitunen 2015). Tutkimuksessamme havaitsemme, että näyttöperusteisuus on kuitenkin kiistanalainen ja itsessään poliittinen ilmiö. Relevantin tiedon kriteerit, tiedontuotantoon vaikuttavat toimijat ja tiedon todellinen vaikutus päätöksentekoon muuttuvat jatkuvasti, mikä tarkoittaa, että tiedontuotanto itsessään on altis myös ulkoapäin ohjautuville muutoksille.

Vaikka tapaustutkimuksemme käsitteli Suomea, on tutkimuksella monia kansainvälisiä ulottuvuuksia. Käytännössä kaikkiin kuvaamiimme veropoliittisen valmistelun murroskohtiin on liittynyt kansainvälisiä vaikutteita. Jo 1970-luvun loppupuolella Suomessa seurattiin tarkkaan brittiläisen James Meaden verokomitean työtä. Reaganin hallinnon ja muiden Pohjoismaiden merkitys oli suuri vuoden 1993 verouudistuksessa, ja 1990-luvun lopussa eurooppaoikeuden ja OECD:n rooli korostui. Britannian Mirrlees Review oli 
keskeinen innoittaja Hetemäen verotyöryhmälle, joka haki vaikutteita myös kansainvälisten talousjärjestöjen tuottamasta taloustieteellisestä tutkimuksesta.

Erään haastateltavan mielestä valmistelussa on "helppo turvautua korkeamman auktoriteetin sanaan ja tavallaan ottaa ohjenuoraksi näiden talousjärjestöjen neuvot” (Haastattelu 2019a). Hyvin harvoilla politiikoilla on uskallusta haastaa näitä neuvoja (emt.). Mahdollisuus valikoida, mitä kansainvälisen tiedontuotannon keskuksia kuunnellaan ja mitä ei, vahvistaa asiantuntijatyöryhmien valtaa keskustelun suodattajina suomalaiseen politiikkaan ja lainvalmisteluun. Tiedon ja politiikan kannalta on olennaista, että tiedontuotanto väistämättä perustuu erilaisille ennakko-oletuksille, lausumattomille käytännöille ja hallitseville tutkimusvirtauksille.

Uusklassisen taloustieteen teoreettisten olettamusten lisäksi on tärkeää korostaa veropolitiikan kulttuurista ja institutionaalista polkuriippuvuutta. Institutionaalisella tasolla valmistelun pitkä linja on osittain riippumaton poliittisen johdon muutoksista. Tämä pitkä linja muotoutuu tietyistä vaikutusvaltaisista asiakirjoista, asteittain muodostuneista käytänteistä sekä instituutioihin kasaantuneista tietovarannoista ja tiedollisista auktoriteeteista. Nämä polkuriippuvuudet ovat muotoutuneet tietyissä historiallisissa konteksteissa vastaamaan aikansa kysymyksenasetteluihin. Esimerkiksi yhteisöveropolitiikassa monet kehityslinjat sekä oppimisprosessit juontavat juurensa 1990-luvun alun lamaan ja ajatuksiin sitä edeltäneen verojärjestelmän tehottomuudesta (Haastattelu 2019a, 2019b). Tämä näkökulma on kytkeytynyt lähtökohtaisesti skeptiseen näkemykseen valtion aktiivisesta roolista talouden ohjaajana. ${ }^{17}$

Ilmakunnas, Junka ja Uusitalo $(2008$, 9) ovat peräänkuuluttaneet erityisesti taloustieteen osalta päätöksentekijöiltä ymmärrystä tutkimuksiin liittyvistä epävarmuuksista. Tapaustutkimuksemme alleviivaa sitä, miten vaikeaa näitä epävarmuuksia käytännössä on ymmärtää tilanteessa, jossa niiden saama huomio vähenee sitä mukaa, kun tutkimustiedosta siirrytään sen hyödyntämiseen ja kun se tulee osaksi poliittisesta uudistuksesta käytävää julkista keskustelua. Vihriälä (2008) onkin peräänkuuluttanut ministeriöiltä parempaa osaamista tutkimusten tulkinnassa ja soveltamisessa. Tämän artikkelin tulokset korostavat samaa katvealuetta, mutta erityisesti siitä näkökulmasta, että eri tieteenalojen ja lähestymistapojen tulisi valikoitua tutkimusaiheen relevanssin 
mukaan - sen sijasta, että esimerkiksi talouspoliittiset kysymykset samastettaisiin yksinomaan kansantaloustieteeseen.

On huomattava, että 2000-luvun ensimmäisen vuosikymmenen tutkimukset eivät sellaisenaan edusta taloustieteellisen verotutkimuksen nykytilaa. Vuosien 2007-2009 finanssikriisin jälkeen esimerkiksi Kansainvälisen valuuttarahaston eli IMF:n ekonomisteilta on tullut paljon tutkimusta verotuksen, talouskasvun ja eriarvoisuuden välisestä suhteesta. Näissä tutkimuksissa on esitetty esimerkiksi, että jos verotulojen suhde bruttokansantuotteeseen on liian alhainen, hidastuu tyypillisesti myös talouskasvu (Kaspar, Jaramillo ja Wingender 2016). Ne ovat painottaneet progressiivisen verotuksen merkitystä oikeudenmukaisen verojärjestelmän pilarina (Kansainvälinen valuuttarahasto 2017; ks. myös OECD 2017).

Politiikka tarvitsee tietoa, joka perustuu muun ohella laajaan oikeudellisten järjestelmien tuntemiseen ja käytäntöön pohjaavaan ymmärrykseen taloudellisten toimijoiden käyttäytymisestä kulloisessakin ajassa. Tällaisen tutkimuksen rinnalla tarvitaan syvällistä ymmärrystä taloudellista toimintaa ohjaavista keskeisistä poliittistaloudellisista instituutioista ja yhteiskunnallisista voimista. Tämä korostaa tapaustutkimusten, laadullisen ja monimenetelmällisen tutkimuksen sekä erilaisten skenaarioiden ja kontrafaktuaalisten lähestymistapojen merkitystä.

Lainvalmistelussa ongelmia ja tiedollisia katvealueita syntyy, jos tarkastelun kannalta relevantit tosiasiat rajataan tutkimuksiin, jotka rakentuvat yksittäisen tieteenalan metodeista, aineistoista ja taustaoletuksista. Tutkimusten lopputulokset voivat tällöin olla niin hyviä kuin kyseisellä tieteenalalla voidaan saavuttaa, mutta samalla ne jäävät huomattavasti rajallisemmiksi kuin tulokset mitä voitaisiin saavuttaa muilla tieteenaloilla tai monitieteellisellä lähestymistavalla.

Näiden huomioiden soveltaminen lainvalmistelun käytäntöön on kuitenkin haasteellista. Todellisuudessa kansainvälisesti verrattuna erittäin vähäiset henkilöresurssit sekä kiireiset aikataulut rajoittavat virkamiesten käytössä olevia tekniikoita sekä mahdollisuuksia ottaa huomioon kaikkia relevantteja tarkastelukulmia. Kuitenkin samanaikaisesti poliittinen johto ja erilaiset instituutiot tarvitsevat useista syistä käyttöönsä selkeitä vaikuttavuusarvioita esitetyistä laeista. Ehdotuksiin liittyvillä epävarmuuksilla on taipumus painua sitä 
enemmän taka-alalle, mitä lähemmäksi poliittista päätöksentekoa prosessissa edetään.

Tämän hankkeen varsinaisen tarkasteluajanjakson jälkeen julkaistiin vuonna 2017 yritysverotuksen asiantuntijatyöryhmän raportti. Vaikka itse työryhmä oli melko juristivoittoinen ${ }^{18}$, sen tehtävää määritteli pitkälti erillisenä valtioneuvoston kanslian tilaustutkimuksena tehty selvitys, jonka VATT ja ETLA olivat tehneet ja jonka yhteyshenkilönä toimi Seppo Kari (VNK 2019; Harju ym. 2017). Tätä vasten voidaan sanoa, että tässä artikkelissa kuvattu tiedontuotannon muutos on säilyttänyt asemansa. Kuitenkin tulevaisuus on tässä suhteessa epävarma. VATT on tutkimusrahoitukseen liittyvien uudistusten myötä alkanut yhä vahvemmin irtautua itsenäiseksi akateemiseksi tutkimuslaitoksekseen. (Haastattelu 2019a, Haastattelu 2019b.) ${ }^{19}$

Vuosien 2007-2009 finanssikriisi ja maailmanpoliittistaloudellisen tilanteen nopea murros korostaa taloutta koskevan yhteiskuntatieteellisen ja empiirisen ymmärryksen tärkeyttä. Talouden kriisitilanteissa poliittiset päätöksentekijät sekä suuri yleisö kääntyvät taloustieteilijöiden puoleen uusien ratkaisujen löytämiseksi (Fourcade ym. 2015, 22). Keskeistä ei ole vain se, miten taloudellinen dynamiikka on eri alueilla toiminut erilaisten (usein puutteellisten) historiallisten tilastoaineistojen ja taustaoletusten valossa. Yhteiskuntatieteissä erilaisten policy-agendojen tutkimusta on perinteisesti tehty yhteiskuntapolitiikassa, mutta sen fokuksena on tyypillisesti ollut sosiaali- ja terveyspolitiikka. Kansainvälisesti talouspolitiikkaan liittyvää policy-tutkimusta tehdään esimerkiksi kriittisen hallinnon tutkimuksen ja globaalin poliittisen talouden tutkimuksen piirissä. Näiden alueiden vahvistamisesta olisi hyötyä myös tietoperusteisen päätöksenteon kehittämisessä.

\section{Tietoa artikkelista}

Tutkimus on saanut tukea Suomen kulttuurirahaston Tutkittu tieto ja päätöksenteko -ohjelmasta. 


\section{Viitteet}

I) Suorien lainausten puhekielisyyttä on stilisoitu luettavuuden parantamiseksi mutta ilman, että tämä on vaikuttanut lainausten sisältöön.

2) 1990-luvun lopulla nousi vaatimuksia sitoa päätöksentekoa aiempaa selvemmin tutkimustietoon, ja viime vuosina "tiedolla johtaminen" on noussut suomalaisen julkishallinnon kehittämistyön valtavirtaan (Lähteenmäki-Smith ja Kuitunen 2015).

3) Tässä yhteydessä taloustieteellä viitataan uusklassisen taloustieteen valtavirtamalliin, jonka perusluonne on pohjimmiltaan "matemaattinen, epäpoliittinen" ja joka "kieltää instituutioiden olennaisuuden" siten kuin instituutiot muissa yhteiskuntatieteissä yleensä ymmärretään, ja jonka pohjana on metodologinen individualismi sekä kuluttajien ja yritysten marginalististen preferenssien tutkimus (Eskelinen 2012). Taloustieteen piirissä tehdään toki tutkimusta myös perusmalleja laajemmin esimerkiksi behavioralistisista lähtökohdista. Näkökulmamme on tässä kuitenkin verotuksen tutkimuksessa. Osassa verotusta koskevan taloustieteen valtavirtatutkimusta käytetään käyttäytymisoletuksia, joiden mahdollisia ongelmia käymme läpi myöhemmin. Toisaalta uusklassisen taloustieteen puitteissa tehdään myös tilastollista tutkimusta, jossa erilaiset käyttäytymisvaikutukset ovat läsnä lähinnä implisiittisesti.

4) Esimerkiksi Haas ja Stevens $(2011,138)$ toteavat, että tiedontuotannon riippumattomuus politiikkaprosessista on elintärkeää, sillä näin varmistetaan tiedon objektiivisuus, mikä on välttämätöntä sen käyttämiseksi politiikkaprosessissa. Vastakkaisesta näkökulmasta katso Lidskog ja Sundqvist 2015.

5) Politiikan tutkimuksessa on identifioitu ainakin kolme tietotarpeiden ideaalityyppiä. Nämä ovat tiedon käyttö politiikan ohjaajana, jo päätettyjen poliittisten kantojen tukijana sekä symbolisen auktoriteetin ja vaikutusvallan saavuttamisen välineenä. (Rimkute \& Haverland 2015, 436-438.) 
6) Tätä voidaan yhtäältä pitää askeleena takaisin kohti entistä mallia. Valtion taloudellinen tutkimuskeskus toimi alun perin valtiovarainministeriön alaisuudessa, josta se irrotettiin itsenäiseksi tutkimuslaitokseksi vuonna 1990 taloudellisen suunnittelukeskuksen ja valtionvarainministeriön suunnittelusihteeristön yhdistyessä.

7) Toisaalta Soudis (2015) toteaa, että luottoluokitusten merkitystä politiikan ohjaajana on liioiteltu eikä datasta voida havaita selkeää korrelaatiota valtion luottoluokitusten ja talouspolitiikan muutosten välillä. Tämä havainto ei kuitenkaan välttämättä poista luottoluokitusten merkitystä politiikkaa ennakkoon määrittävänä tekijänä.

8) Neutraaliudella tarkoitetaan verotuksen ohjausvaikutuksen minimoimista yritysten ja kuluttajien taloudellisissa päätöksissä.

9) Esimerkiksi kiinteistövero on yksi verolaji, joka nimenomaan Suomessa on veronmaksajien keskuudessa erittäin epäsuosittu, vaikka sitä pidetään taloustieteellisen tutkimuksen valossa tehokkaana ja oikeudenmukaisena. (Haastattelu 2019a.)

Io) On tosin aiheellista huomata, että samaan aikaan Arvelan työryhmän perustamisen kanssa valtioneuvoston kanslia tilasi talousneuvostolta raportin Suomen verojärjestelmän muutostarpeista (Talousneuvosto 2002). Tässä asiantuntijaryhmässä taloustieteen professio oli keskeisesti edustettuna, minkä lisäksi raportin tiedonmuodostus nojasi vahvasti taloustieteelliseen argumentaatioon. Raportti ei kuitenkaan saanut merkittävää asemaa veropoliittisessa valmistelussa. (Niskakangas 2019.)

II) Kuviossa esitetään nimellinen yhteisöverokanta (statutory corporate tax rate), jossa yhdistyy sekä kunta- että valtiotason verotus. Tilasto ei kerro verojärjestelmään sisältyvistä poikkeuksellisista piirteistä, joilla voi olla suurta merkitystä yhteisöverotuksen tosiasialliseen tasoon eli efektiiviseen verokantaan.

I2) Verojärjestelmän kehittämisen piti myös tukea työllisyyden ja tuottavuuden kasvua (VM 2010b, 12). 
I3) Valtion taloudellisen tutkimuslaitoksen raportti Suomen hyvän veropolitiikan perusteista oli tehnyt saman huomion (Kari, Rauhanen, Eerola, Kosonen, Lyytikäinen, ja Saarimaa, 2013, 36-37), ja verokilpailun merkitystä painotettiin myös uudistusta jälkikäteen käsitelleessä Valtiontalouden tarkastusviraston raportissa (VTV 2014, 13).

I4) Toinen julkilausuttu tavoite oli vuoden 1993 tapaan verotuksen neutraalisuuden lisääminen, jonka ajateltiin lisäävän taloudellista tehokkuutta (esimerkiksi VTV 2014, 9). Kuten aiemmin nähtiin, verotuksen neutraalisuuden argumentti oli erittäin keskeisessä osassa jo Holkerin kokonaisverouudistuksessa ja erityisesti vuoden 1993 verouudistuksessa, joissa ajatus laajoista veropohjista ja suhteellisen matalista verokannoista muotoutui suomalaisen veropolitiikan pitkän aikavälin ohjaavaksi periaatteeksi.

I5) Valtiovarainministeri Urpilainen menetti paikkansa puolueen johdossa seuraavassa puoluekokouksessa, osittain juuri yhteisöveron alennukseen liittyen (Parkkonen 2019).

I6) Yleisen tasapainon malliin pohjautuvien ennustemallien merkitys on lisääntynyt yleisesti valtionhallinnon ohjaamisessa. DSGE-ennusteiden luotettavuus on herättänyt viime aikoina kansainvälisesti laajaa kriittistä keskustelua. Jotkut ovat syyttäneet niitä jopa "makrotaloustieteen rappiosta" (Romer 2015), toiset hieman lempeämmin "epärealistisista mutta korjauskelpoisista oletuksista" (Blanchard 2018). Suomessa DSGE-mallien käyttöä ovat kritisoineet esimerkiksi Heikki Patomäki (2018, 2015), Heikki Taimio (2016) ja Eero Lehto (2011).

I7) Tämä näkökulma jättää ajoittain vähemmälle huomiolle Pohjoismaiden historiallisen kehityksen 1980-luvulle asti, jossa valtion vahvasta osallistumisesta ja uudelleenjakavasta roolista huolimatta saavutettiin sosiaalisesti kestävää taloudellista kehitystä, joka johti nykymuotoisen hyvinvointivaltiorakenteen muodostumiseen. Tätä näkökulmaa uusintaa myös varsinkin kansainvälisten talousjärjestöjen taipumus asettaa angloamerikkalainen, valtion keveään osallistumiseen nojaava veromalli maaraporttien benchmarkiksi (Haastattelu 2019a). 
I8) Työryhmän puheenjohtajana toimi ylijohtaja Terhi Järvikare valtiovarainministeriöstä ja jäseninä OTT, dosentti Pauli K. Mattila, professori emeritus Heikki Niskakangas Aalto-yliopistosta, finanssioikeuden professori Jaakko Ossa Turun yliopistosta, OTT, toimitusjohtaja Timo Viherkenttä Valtion eläkerahastosta ja (erityisasiantuntija, sittemmin) lainsäädäntöneuvos Tarja Järvinen valtiovarainministeriöstä. Työryhmän sihteereinä toimivat lainsäädäntöneuvos Tarja Järvinen ja finanssisihteeri Ilari Valjus valtiovarainministeriöstä. Työryhmän asiantuntijoina toimivat finanssineuvos Jari Salokoski, finanssineuvos Elina Pylkkänen, hallitusneuvos Panu Pykönen ja erityisasiantuntija Anu Rajamäki valtiovarainministeriöstä. (VM 2017, 7.)

I9) Taloustiede on kuitenkin vakiinnuttanut yleisesti identiteettiään keskeisenä ennustamiseen kykenevänä tieteenä myös Suomessa. Vuoden 2018 keväällä Helsinkiin perustettiin julkisella ja yksityisellä rahalla uusi taloustieteellinen jatkokoulutusyksikkö Helsinki Graduate School of Economics, jonka julkilausuttuna tavoitteena on olla kansainvälisessä vertailussa tunnustettu huippuyksikkö ja yhteiskunnan kehitystä ohjaava voima. (HGSE 2019.)

\section{Lähteet}

af Ursin, Klaus ja Vartola, Juha. 2015. Valtionhallinnon kehitystä ohjaavat hallintoideologiat, hallintoajattelu ja johtamismallit. Teoksessa Petri Virtanen, Jari Stenvall ja Pasi-Heikki Rannisto (toim.), Tiedolla johtaminen: Teoriaa ja käytäntöjä. Tampere: Tampere University Press, 89-114.

Andersson, Edward. 1994. Pääomatulon verotus. Helsinki: Lakimiesliiton kustannus.

Anguelov, Nick. 2015. Lowering the Marginal Corporate Tax Rate: Why the Debate? 1PPC Working Paper Series, Work Paper No. PMG/2015/01. Dartmouth: University of Massachusetts. Blanchard, Olivier. 2018. On the future of macroeconomic models. Oxford Review of Economic Policy, 34:1-2, 43-54. 
Blyth, Mark. 2011. Ideas, uncertainty, and evolution. Teoksessa Daniel Béland ja Robert Henry Cox,(toim.), Ideas and politics in social science research. Oxford: Oxford University Press, 83-101.

Campbell, John ja Pedersen, Ove. 2014. The national origins of policy ideas: Knowledge regimes in the United States, France, Germany, and Denmark. Princeton: Princeton University Press.

Christensen, John. 2017. The power of economists within the state. Stanford: Stanford University Press.

Clausing, Kimberly. 2016. The Effect of Profit Shifting on the Corporate Tax Base. National Tax Journal 69:4, 905-934.

De Mooij, Ruud ja Ederveen, Sjef. 2008. Corporate tax elasticities: a reader's guide to empirical findings. Oxford Review of Economic Policy 24:4, 680-697. Eräsaari, Leena. 2011. Sosiaalipalvelut käännöksen jälkeen. Teoksessa Elina Palola ja Vappu Karjalainen (toim.), Sosiaalipolitiikka - Hukassa vai uuden jäljillä? Helsinki: Terveyden ja hyvinvoinnin laitos, 181-203.

Eskelinen, Teppo. 2012. Taloustieteen normatiivisuus ja hyvinvoinnin tulkinnat. Niin \& näin 3:2012, 79-86.

Finér, Lauri ja Ylönen, Matti. 2017. Tax-driven wealth chains: A multiple case study of tax avoidance in the Finnish mining sector. Critical Perspectives on Taxation 48:2017, 53-81.

Fourcade, Marion. 2006. The Construction of a Global Profession: The Transnationalization of Economics. American Journal of Sociology 112:1, 145-94.

Fourcade, Marion, Etienne Ollion, and Yann Algan. 2015. The superiority of economists. Journal of economic perspectives 29:1, 89-114.

Haas, Peter. 1992. Introduction: epistemic communities and international policy coordination. International organization, 46:1 1-35.

Haas, Peter ja Stevens, Casey. 2015. Organized science, usable knowledge, and multilateral environmental governance. Teoksessa Rolf Lidskog ja Göran Sundqvist (toim.), Governing the air: The dynamics of science, policy, and citizen interaction. Cambridge, MA: MIT Press, 125-161.

Haastattelu 2019a. Hankkeen puitteissa tehty haastattelu, anonyymi. Helsinki. Haastattelu 2019b. Hankkeen puitteissa tehty haastattelu, anonyymi. Helsinki. Haastattelu 2019c. Hankkeen puitteissa tehty haastattelu, anonyymi. Helsinki. Haastattelu 2019d. Hankkeen puitteissa tehty haastattelu, anonyymi. Helsinki 
Haastattelu 2019e. Hankkeen puitteissa tehty haastattelu, anonyymi. Helsinki. Haastattelu 2019f. Hankkeen puitteissa tehty haastattelu, anonyymi. Helsinki. Harju, Jarkko, Kari, Seppo, Koivisto, Aliisa, Kuusi, Tero, Matikka, Tuomas, Määttänen, Niku, Pajarinen, Mika, Ropponen, Olli, Rouvinen, Petri ja Valkonen, Tarmo. 2017. Yritysverotus, investoinnit ja tuottavuus. Valtioneuvoston selvitys- ja tutkimustoiminnan julkaisusarja 6:2017. Helsinki: Valtioneuvoston kanslia.

Heino, Saska. 2015. Uusjako? Vuoden 1993 tuloverouudistus, verohistoria ja pääoma. Pro gradu -työ. Turku: Turun yliopisto.

Heiskala, Risto ja Luhtakallio, Eeva (toim.). 2006. Uusi jako. Miten Suomesta tuli kilpailukyky-yhteiskunta? Helsinki: Gaudeamus. Helsinki Graduate School of Economics. 2019. Vision. www.helsinkigse.fi/about [Luettu 7.1.2020]

Hietala, Harri, Kari, Seppo, Rauhanen, Timo ja Ulvinen, Hanna. 2004. Laskelmia yritys- ja pääomaverouudistuksesta. Helsinki: Valtion taloudellinen tutkimuskeskus.

Hjerppe, Reino, Kari, Seppo, Kiander, Jaakko ja Poutvaara, Panu. 2003. Verokilpailu ja Suomen verojärjestelmä. Vantaa: Dark.

Honkanen, Pertti. 1993. Vuosisadan verouudistukset: häviäjät ja voittajat. Helsinki: Hanki ja jää.

Honkatukia, Juha. 2009. VATTAGE - A dynamic, applied general equilibrium model of the Finnish economy. VATT Research reports 150. Helsinki: Valtion taloudellinen tutkimuslaitos.

Honkatukia, Juha ja Ahokas, Jussi. 2012. Pitkän aikavälin talousnäkymistä. Kansantaloustieteellinen aikakauskirja 108:3, 279-285.

Hyytinen, Ari ja Toivanen, Otto. 2010. Tutkimuksen hyödyntäminen poliittisessa päätöksenteossa. Kansantaloustieteellinen aikakauskirja 106:4, 426-436.

Hyytinen, Tuomas. 2015. 800 miljoonan verovedätys. Yle MOT, 11.5.2015. https://yle.fi/aihe/ohjelma/mot-800-miljoonan-verovedatys-1152015 [Luettu 7.1.2020]

Ilmakunnas, Seija, Junka, Teuvo ja Uusitalo, Roope. 2008. Politiikkatoimenpiteiden arviointi: Mitä, miten, miksi? Teoksessa Seija Ilmakunnas, Teuvo Junka ja Roope Uusitalo (toim.), Vaikuttavaa tutkimusta - miten arviointitutkimus palvelee päätöksenteon tarpeita? VATT-julkaisuja 47. Helsinki: Valtion taloudellinen tutkimuskeskus, 1-10. 
Jäs̈keläinen, Atte. 1991. Verot taas täysremonttiin Suomi vastaa Euroopan verokilpailuun alhaisella yritysverokannalla: pääomatulojen verosirkus korvataan kattavalla 25-30 prosentin verolla. Helsingin Sanomat, 12.11. https:// www.hs.fi/talous/art-2000003102426.html [Luettu 7.1.2020]

Kansainvälinen valuuttarahasto. 2017. IMF Fiscal Monitor: Tackling Inequality. Lokakuu 2017. Washington D.C.: Kansainvälinen valuuttarahasto.

Kantola, Anu. 2002. Markkinakuri ja managerivalta: Poliittinen hallinta Suomen 1990-luvun talouskriisissä. Helsinki: Loki-kirjat.

Kari, Seppo ja Ropponen, Olli. 2014. Literature review of the dynamic effects of corporate income taxation. VATT Mimeo 40. Helsinki: Valtion taloudellinen tutkimuskeskus.

Kari, Seppo, Rauhanen, Timo, Eerola, Essi, Kosonen, Tuomas, Lyytikäinen, Teemu ja Saarimaa, Tuukka. 2013. Hyvän veropolitiikan periaatteet. VATT julkaisut 63. Helsinki: Valtion taloudellinen tutkimuskeskus.

Kaspar, Vitor, Jaramillo, Laura ja Wingender, Philippe 2016. Tax Capacity and Growth: Is there a Tipping Point? IMF Working Paper WP/16/234. Washington, D.C.: Kansainvälinen valuuttarahasto.

Kauppinen, Ilpo, Harju, Jarkko ja Ropponen, Olli. 2017. Responses to an Interest Barrier: Empirical Evidence. VATT Working Papers 90. Helsinki: Valtion taloudellinen tutkimuskeskus.

Klemm, Alexander ja Van Parys, Stefan. 2009. Empirical Evidence on the Effects of Tax Incentives. IMF Working Paper WP/09/136. Washington, D.C.: Kansainvälinen valuuttarahasto.

Koikkalainen, Petri. 2012. Managerialismi ideologiana. Niin \& näin 4:2012, 42-50.

Konttinen, Jussi. 2019. Minne verottaja ei yllä. Helsingin Sanomat, 2.11. https:// www.hs.fi/sunnuntai/art-2000006293438.html [Luettu 7.1.2020]

Kuusela, Hanna ja Ylönen, Matti. 2013. Konsulttidemokratia: Miten valtiosta tehdään tyhmä ja tehoton. Helsinki: Gaudeamus.

Lehto, Eero. 2011. DSGE-mallien ongelmista. Kansantaloudellinen aikakauskirja 1:2011, 12-16.

Lidskog, Rolf ja Sundqvist, Göran. 2015. When does science matter? International relations meets science and technology studies. Global Environmental Politics, 15:1, 1-20. 
Linsi, Lukas. 2019. The discourse of competitiveness and the dis-embedding of the national economy. Review of International Political Economy, 1-25.

Lähteenmäki-Smith, Kaisa ja Kuitunen, Soile. 2015. Näyttöperusteisuus päätöksenteossa: Tiede- ja tutkimusperusteisuudesta tekemisen demokratiaan? Teoksessa Petri Virtanen, Jari Stenvall ja Pasi-Heikki Rannisto (toim.), Tiedolla johtaminen: Teoriaa ja käytäntöjä. Tampere: Tampere University Press, 115-149.

Maunu, Tallamaria. 2014. Taustamateriaalia valtiontalouden tarkastusviraston raporttiin. Helsinki: Valtiontalouden tarkastusvirasto.

Maunu, Tallamaria ja Korpela, Tomi. 2014. Taustamateriaalia valtiontalouden tarkastusviraston raporttiin. Helsinki: Valtiontalouden tarkastusvirasto.

Marr, Chuck ja Huang, Chye-Ching. 2014. Repatriation tax holiday would lose revenue and is a proven policy failure. Working paper. Washington D.C.:

Center on Budget and Policy Priorities.

Mirrlees, James. 2010. Dimensions of Tax Design. The Mirrlees Review. Työryhmä: Adam, Stuart, Besley, Timothy, Blundell, Richard, Bond, Stephen, Chote, Robert, Gammie, Malcolm, Johnson, Paul, Myles, Gareth ja Poterba, James. Oxford: Oxford University Press.

Mirowski, Philip. 1982. What's wrong with the Laffer Curve? Journal of Economic Issues, 16:3, 815-828.

Niskakangas, Heikki. 2019. Hankkeen puitteissa tehty haastattelu, Helsinki. OECD. 2010. Finland: Working together to sustain success. OECD Public governance reviews. Pariisi: OECD.

OECD. 2017. The Role and Design of Net Wealth Taxes in the OECD. OECD Tax Policy Studies No. 26. Pariisi: OECD.

OECD. 2019. Corporate Tax Statistics Database. http://www.oecd.org/tax/beps/ corporate-tax-statistics-database.htm [Luettu 4.1.2020]

OM. 2007. Säädösehdotusten vaikutusten arviointi: ohjeet. Oikeusministeriö julkaisu 2007:6. Helsinki: Oikeusministeriö.

Parkhurst, Justin. 2017. The politics of evidence: from evidence-based policy to the good governance of evidence. Abingdon: Routledge. 
Parkkonen, Tommi. 2019. Uutuuskirja: Näin Antti Rinne syrjäytti Jutta Urpilaisen Sdp:n johdosta - "Jutta meni tekemään kardinaalimokan". Kauppalehti, 24.10. https://www.kauppalehti.fi/uutiset/uutuuskirja-nainantti-rinne-syrjaytti-jutta-urpilaisen-sdpn-johdosta-jutta-meni-tekemaankardinaalimokan/ [Luettu 7.1.2020]

Patomäki, Heikki. 2018. Uusklassisen talousteorian poliittisuudesta. Politiikka 60:1, 50-67.

Patomäki, Heikki. 2015. VM:n virkamiesraportti on myös älyllisesti epärehellinen. https://patomaki.fi/2015/03/vmn-virkamiesraportti-on-myosalyllisesti-eparehellinen/ [Luettu 8.12.2019]

Paudyn, Bartholomew. 2013. Credit rating agencies and the sovereign debt crisis: Performing the politics of creditworthiness through risk and uncertainty. Review of International Political Economy, 20:4, 788-818.

Pedersen, Ove. 2010. Institutional Competitiveness: How Nations came to Compete?. Teoksessa Glen Morgan ym. (toim.), The Oxford Handbook of Comparative Institutional Analysis. Oxford: Oxford University Press, 625-657. Pekkanen, Maarit. 2019. Hankkeen puitteissa tehty haastattelu. Helsinki. Raeste, Juha-Pekka. 2013. Valtiontalouden tarkastusvirasto moittii kehysriihen valmistelua ja laskelmia. Helsingin Sanomat, 3.5. https://www.hs.fi/politiikka/ art-2000002636068.html [Luettu 7.1.2020]

Raitasuo, Santtu. 2018. Ideologinen laintulkinta vero-oikeudessa. Lakimies 3-4:2018, 363-386.

Raitasuo, Santtu. 2019. Verosuunnittelun tiede? Tapaustutkimus akateemisen verotutkimuksen sidonnaisuuksista. Lakimies 6:2019, 695-726.

Rantanen, Miska ja Suominen, Heli. 2013. Yritysveroalen rahoitus perustuu toiveisiin. Helsingin Sanomat, 28.3. https://www.hs.fi/kotimaa/ art-2000002628325.html [Luettu 7.1.2020]

Rimkute, Dovilé ja Haverland, Markus. 2015. How does the European Commission use scientific expertise? Results from a survey of scientific members of the Commission's expert committees. Comparative European Politics, 13:4, 430-449.

Silfverberg, Kalle. 2013. Hallitus valitsi keveän osinkoveron ohi virkamiesten. Helsingin Sanomat, 19.4. https://www.hs.fi/kotimaa/art-2000002633057.html Sorsa, Ville-Pekka ja Eskelinen, Teppo. 2018. Taloustieteellinen asiantuntemus teknotaloudellisessa kapitalismissa. Politiikka, 60:1, 79-88. 
Soudis, Dimitrios. 2015. Credit rating agencies and the IPE: not as influential as thought? Review of International Political Economy, 22:4, 813-837.

Steinmo, Sven. 2003. The evolution of policy ideas: tax policy in the 20th century. The British Journal of Politics and International Relations, 5:2, 206-236.

Strassheim, Holger ja Kettunen, Pekka. 2014. When does evidence-based policy turn into policy-based evidence? Configurations, contexts and mechanisms. Evidence \& Policy, 10:2, 259-277.

Talousneuvosto. 2002. Verotus kansainvälisessä toimintaympäristössä. Valtioneuvoston kanslian julkaisusarja 2002:5. Helsinki: Valtioneuvoston kanslia.

Talouspolitiikan arviointineuvosto. 2015. Talouspolitikan arviointineuvoston raportti 2014. Helsinki: Talouspolitiikan arviointineuvosto. https://www. talouspolitiikanarviointineuvosto.fi/wordpress/wp-content/uploads/2016/05/ talouspolitiikan_arviointineuvoston_raportti_2014.pdf [Luettu 8.12.2019]

Taimio Heikki. 2016. Makromallien kanssa saa olla varuillaan. Talous $\mathcal{E}$ Yhteiskunta 3:2016, 1.

Tilastokeskus. 2006. Varakkaimman kymmenyksen osuus nettovaroista 47 prosenttia. https://www.stat.fi/til/vtutk/2016/vtutk_2016_2018-06-05_ kat_003_fi.html [Luettu 8.1.2019]

Tilastokeskus. 2019. Taloudellinen kasvu - Bruttokansantuotteen volyymin muutos neljänneksittäin 1991Q1-2019Q3. https://findikaattori.fi/en/table/3 [Luettu 8.12.2019]

Tuomala, Matti. 2019. Markkinat, valtio \& eriarvoisuus. Tampere: Vastapaino.

Turkkila, Juhani. 2011. Tuloverotuksen reaalinen muuttuminen Suomessa: kuusikymmentä vuotta verojen vuoristorataa. ETLA Sarja A, 46. Helsinki: Taloustieto Oy.

Tørsløv, Thomas, Wier, Ludwig ja Zucman, Gabriel. 2018. The Missing Profits of Nations. NBER Working paper series, Working Paper 24701. Cambridge, MA: National Bureau of Economic Research.

Valtanen, Teijo. 2019. Analyysi: Lobbarien osinkoveromalli puhuu raikkaasti työelämän tarpeista, mutta kompastuu riitelyyn veronalennuksista. Yle 28.2. https://yle.fi/uutiset/3-10667303 [Luettu 8.12.2019]

Veronmaksajat. 2019. Yhteisöverotus. https://www.veronmaksajat.fi/luvut/ Tilastot/Tuloverot/Yhteisoverotus/\#6cf372cc [Luettu 4.1.2020] Viherkenttä, Timo. 2019. Hankkeen puitteissa tehty haastattelu. Helsinki. 
Vihriälä, Vesa. 2008. Politiikka-analyysi (talous)politiikassa. Teoksessa Seija Ilmakunnas, Teuvo Junka, Teuvo ja Roope Uusitalo (toim.), Vaikuttavaa tutkimusta - miten arviointitutkimus palvelee päätöksenteon tarpeita? VATTjulkaisuja 47. Helsinki: Valtion taloudellinen tutkimuskeskus, 11-38.

VM. 1991. Pääomatulojen verotuksen ja yritysverotuksen kehittämislinjat Asiantuntijatyöryhmän muistio. Valtiovarainministeriön työryhmämuistioita 1991:28. Helsinki: Valtiovarainministeriö.

VM. 1992. Yritysverouudistuksen taloudellisia vaikutuksia selvittäneen työryhmän muistio. Valtiovarainministeriön työryhmämuistioita 1992:23. Helsinki: Valtiovarainministeriö.

VM. 2002. Kilpailukykyiseen verotukseen. Tuloverotuksen kehittämistyöryhmän muistio. Valtiovarainministeriön työryhmämuistioita 12:2002. Helsinki: Valtiovarainministeriö.

VM. 2010a. OECD:n Suomen hallinnon maa-arviointi: Käännös tiivistelmästä ja keskeisistä suosituksista. Kesäkuu 2010. Helsinki: Valtiovarainministeriö.

VM. 2010b. Verotuksen kehittämistyöryhmän väliraportti. Valtiovarainministeriön julkaisuja 35:2010. Helsinki: Valtiovarainministeriö. VM. 2010c. Verotuksen kehittämistyöryhmän loppuraportti. Valtiovarainministeriön julkaisuja 51:2010. Helsinki: Valtiovarainministeriö. VM. 2013. Valtiontalouden kehykset vuosille 2014-2017. VM/1611/2.02.00.00/2012. 27.3.2013, tarkistettuna 8.4.2013. Helsinki: Valtiovarainministeriö.

VM. 2017. Yritysverotuksen asiantuntijatyöryhmän raportti. Valtiovarainministeriön julkaisu 12:2017. Helsinki: Valtiovarainministeriö. VNK. 1991. Pääministeri Esko Ahon hallituksen ohjelma. https://valtioneuvosto. fi/hallitusohjelmat/-/asset_publisher/65-paaministeri-esko-ahon-hallituksenohjelma [Luettu 27.12.2019]

VNK. 2007. Hallituksen strategia-asiakirja. Helsinki: Valtioneuvoston kanslia. VNK 2011. Poliittisen päätöksenteon tietopohjan parantaminen - tavoitteet todeksi Politiikkatoimien vaikuttavuusarvioinnin kehittämistyöryhmän raportti. Valtioneuvoston kanslian julkaisusarja 8/2011. Helsinki: Valtioneuvoston kanslia.

VNK. 2019. Yritysverotus, investoinnit ja tuottavuus. https://tietokayttoon. fi/hankkeet/hanke-esittely/-/asset_publisher/yritysverotus-investoinnit-jatuottavuus [Luettu 14.12.2019] 
VTV. 2014. Veromuutosten taloudelliset vaikutukset - yhteisö- ja pääomaverotus. Valtiontalouden tarkastusviraston tarkastuskertomus 13:2014. Helsinki: Valtiontalouden tarkastusvirasto.

Yle. 2013a. Yhteisöveron dynaamisia vaikutuksia liioiteltu. Yle Uutiset, 22.3. https://yle.fi/uutiset/3-6551318 [Luettu 8.12.2019]

Yle. 2013b. Hallituksen veroratkaisuille kritiikkiä - "laskelmat täysin hihasta tempaistut". Yle Uutiset, 22.3. https://yle.fi/uutiset/3-6549337 [Luettu 10.12.2019]

Ylönen, Matti ja Kuusela, Hanna. 2018. Consultocracy and its discontents: A critical typology and a call for a research agenda. Governance 32:2, 241-258.

\section{Liite 1: haastateltavat}

Marko Junkkari, toimittaja, Helsingin Sanomat

Liisa Laakso, entinen jäsen, Talouspolitiikan arviointineuvosto

Pasi Holm, tutkimusjohtaja, Taloustutkimus Oy

Pertti Honkanen, entinen johtava tutkija, KELA

Jukka Pirttilä, professori, Helsingin yliopisto ja VATT

Seppo Kari, johtava tutkija, VATT

Matti Tuomala, professori, Tampereen yliopisto

Ekonomisti, valtionhallinto (anonymisoitu)

Ilari Valjus, erityisasiantuntija, valtiovarainministeriö

Jukka Pekkarinen, entinen kansantalousosaston ylijohtaja, valtiovarainministeriö

Timo Viherkenttä, toimitusjohtaja, Valtion Eläkerahasto

Poliittinen taustavaikuttaja, eduskuntapuolue (anonymisoitu)

Janne Juusela, osakas, Borenius Asianajotoimisto Oy

Maarit Pekkanen, entinen valiokuntaneuvos, eduskunnan

valtiovarainvaliokunnan verojaosto

Vesa Vihriälä, työelämäprofessori, Helsingin yliopisto

Matti Vanhanen, eduskunnan puhemies

Martti Hetemäki, valtiosihteeri, valtiovarainministeriö

Lasse Arvela, entinen vero-osaston ylijohtaja, valtiovarainministeriö 
Ylönen, JaAkkola, SaAri \& Hillamo

Politttinen talous 8(2020):1, 27-69

Heikki Niskakangas, emeritusprofessori, Aalto-yliopisto

Jussi Järventaus, entinen toimitusjohtaja, Suomen Yrittäjät

Yksi haastateltu henkilö ei antanut lupaa haastattelunsa käyttöön tutkimuksessa. 